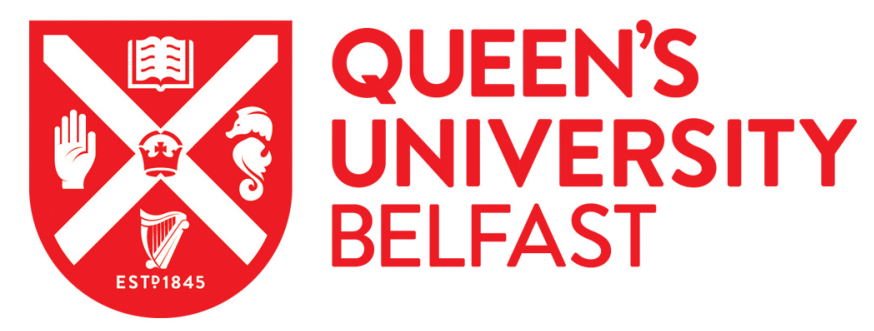

\title{
Barriers and facilitators to shellfish cultivation
}

Fox, M., Service, M., Moore, H., Dean, M., \& Campbell, K. (2019). Barriers and facilitators to shellfish cultivation. Reviews in Aquaculture. https://doi.org/10.1111/raq.12325

\section{Published in:}

Reviews in Aquaculture

\section{Document Version:}

Peer reviewed version

\section{Queen's University Belfast - Research Portal:}

Link to publication record in Queen's University Belfast Research Portal

\section{Publisher rights}

(c) 2019 Wiley Publishing Asia Pty Ltd. This work is made available online in accordance with the publisher's policies. Please refer to any applicable terms of use of the publisher.

\section{General rights}

Copyright for the publications made accessible via the Queen's University Belfast Research Portal is retained by the author(s) and / or other copyright owners and it is a condition of accessing these publications that users recognise and abide by the legal requirements associated with these rights.

Take down policy

The Research Portal is Queen's institutional repository that provides access to Queen's research output. Every effort has been made to ensure that content in the Research Portal does not infringe any person's rights, or applicable UK laws. If you discover content in the Research Portal that you believe breaches copyright or violates any law, please contact openaccess@qub.ac.uk. 
1 Barriers and Facilitators to Shellfish Cultivation

2

3 Michaela Fox $^{1}$, Matt Service ${ }^{2}$, Heather Moore ${ }^{2}$, Moira Dean ${ }^{1}$ and Katrina Campbell ${ }^{1}$

4

$5{ }^{1}$ Institute for Global Food Security, School of Biological Sciences, Queen's University Belfast, 6 David Kerr Building, Stranmillis Road, Belfast, BT9 5AG.

$7 \quad{ }^{2}$ Agri-Food and Biosciences Institute, 18a Newforge Lane, Belfast, County Antrim, Northern 8 Ireland, UK, BT9 5PX.

9

10 Corresponding Author:

11 Dr Katrina Campbell, Institute for Global Food Security, School of Biological Sciences.

12 Queen's University, David Kerr Building, Stranmillis Road, Belfast, BT9 5AG. Tel: + 44 (0) 2890976535. Fax: +44 (0) 2890976513. Email: katrina.campbell@qub.ac.uk

Running Title: Shellfish Cultivation in Northern Ireland 


\section{Abstract}

23 A literature review was conducted to determine the barriers and facilitators to shellfish 24 cultivation using Northern Ireland (NI) as a case study. This review included 23 papers, 25 published in 14 journals, indexed in the Web of Science database. The eligibility criteria included (i) peer reviewed articles or websites from key government or agency stakeholders in the aquaculture supply chain; (ii) had a primary focus on shellfish production and; (iii) made reference to the United Kingdom, Ireland or Northern Ireland. Six key categories were identified as impacting the aquaculture sector; Economic, Environmental, Technical, Welfare, Political and Consumer factors. The most commonly cited codes within these categories included: regulations, management decisions, environmental welfare, weather conditions, consumer needs and water quality. Within the scientific literature the study designs were variable and NI specific data was limited. However, the recommendations were relatively consistent. More evidence-based data collection is needed to better establish the status of the aquaculture industry in this region and to provide more effective management practices and recommendations. The information gained from this review allowed the identification and discussion of the challenges and opportunities for shellfish production worldwide; an insight into production in NI; and preliminary recommendations for improving this industry. As a result, the review offers important foundations and lessons for other aquaculture production units across the world to assess their industry.

41 Keywords: Aquaculture Production, Bivalve Mollusc, Food Quality, Food Safety, Supply 
Aquatic food makes an important contribution to human health and nutrition, particularly as an animal protein resource, and is enjoyed by consumers for cultural and gastronomic reasons (Jennings et al., 2016; Clegg et al., 2014). It is sourced from the wild fisheries (capture of aquatic animals from the wild for commercial value) or aquaculture (farming of aquatic organisms such as fish, crustaceans or molluscs) (DAERA, 2018). This aquatic food must be safe, sufficient, and nutritious to fulfil the needs and wants of the consumers, whilst achieving environmental, social and economic sustainability to provide for the long term (Jennings et al., 2016). These requirements can be challenging due to: the growing global human population, expected to grow from 7.6 billion to 9.8 billion by 2050 (United Nations, 2017); the increased demand as a result of a growing 'middle class' sector who have greater spending power and typically consume more animal protein than people with lower incomes (Kharas, 2010); and the state of the wild stocks which are approaching their maximum sustainable potential (Clegg et al., 2014; Read and Fernandes, 2003). In order to achieve these increasing requirements the aquaculture industry has become a vital source of production over the last 30 years, increasing from less than 1 million tonnes per year in the early 1950's to 60 million tonnes in 2010 (FAO, 2010). Consequently, this sector has become one of the fastest producing industries worldwide and an essential source of food, nutrition, income and livelihood for billions of people around the world (FAO, 2016, Clegg et al., 2014). A further 140million tonnes of aquaculture produce is predicted for 2050 if demands for aquatic food are to be met (Waite et al., 2014). At present, production primarily occurs in the developing countries, particularly Asia, whilst, the annual growth rates of developed and industrialised counties have stagnated. (FAO, 2017a; European Commission, 2016; Jennings et al., 2016).

Northern Ireland (NI) appears to have a comparative advantage, in terms of temperature regime and suitable sites for the production of shellfish species, namely Pacific oysters (Crassostrea 
gigas or Magallana gigas), Mussels (Mytilus edulis) and Native oysters (Ostrea edulis). In this region, these species benefit from a good health status with the absence of notifiable diseases, except for localised cases of Bonamia ostreae and Marteilla Refringens (DAERA, 2018). There is currently 46 farms licenced for the cultivation of shellfish directly employing 91 full time and 78 part time employees (DAERA, 2018). These are mainly small-medium or micro enterprises based around the five sea loughs in Northern Ireland providing jobs and revenue to the local economy (Fig. 1). This sector often compliments employment in inshore fishing, tourism and small-scale agriculture especially at times when income from these other activities may be insufficient to consistently sustain a livelihood, making an important contribution to social cohesion (BIM, 2008). Motivations range from meeting immediate subsidence needs to gathering substantial income for multinational companies trading in export markets (Jennings et al., 2016). Shellfish cultivation has the potential to make an important contribution to the environment through their filter feeding features which can benefit water quality and ecosystem integrity (Marquis et al., 2015; Coen et al., 2007). Despite these distinct benefits of shellfish cultivation, production in the region remains relatively stationary at 3,438 tonnes worth $£ 4.3$ million in 2016 in comparison to 3,469 tonnes worth $£ 3.6$ million in 2015 (Table 1) (DAERA, 2018; FAO, 2017). Although, these figures do not account for production in Lough Foyle (circled in red in Fig. 1) where there is an estimated 30,000 unlicensed oyster trestles (BBC News, 2016). This Lough shares a border with the Republic of Ireland and both regions are in a political dispute over ownership. As a result neither authority has the power to regulate or control the spread of oyster farmers. There are some signs that shellfish cultivation in NI may be entering a growth stage (Habrey and Evans, 2016; Murray et al., 2012), but major constraints such as seed, site availability, water quality, pathogens and consumer perceptions continue to inhibit the industry (Alexander et al., 2015; Oidtmann et al., 2011; Simard et al., 2008; Kaiser and Stead, 2002). As a result NI has underperformed in comparison to the 
worldwide growth rates over the last three decades (Habrey and Evans, 2016). It is therefore essential to identify and address the current barriers to shellfish production in NI and illustrate the unrealised potential in this region. The aim of this study is to determine both the barriers and facilitators to aquaculture production in NI and provide recommendations for the construction of a strategic approach to address such issues and allow this sector to capitalise on the worldwide markets and opportunities for shellfish production.

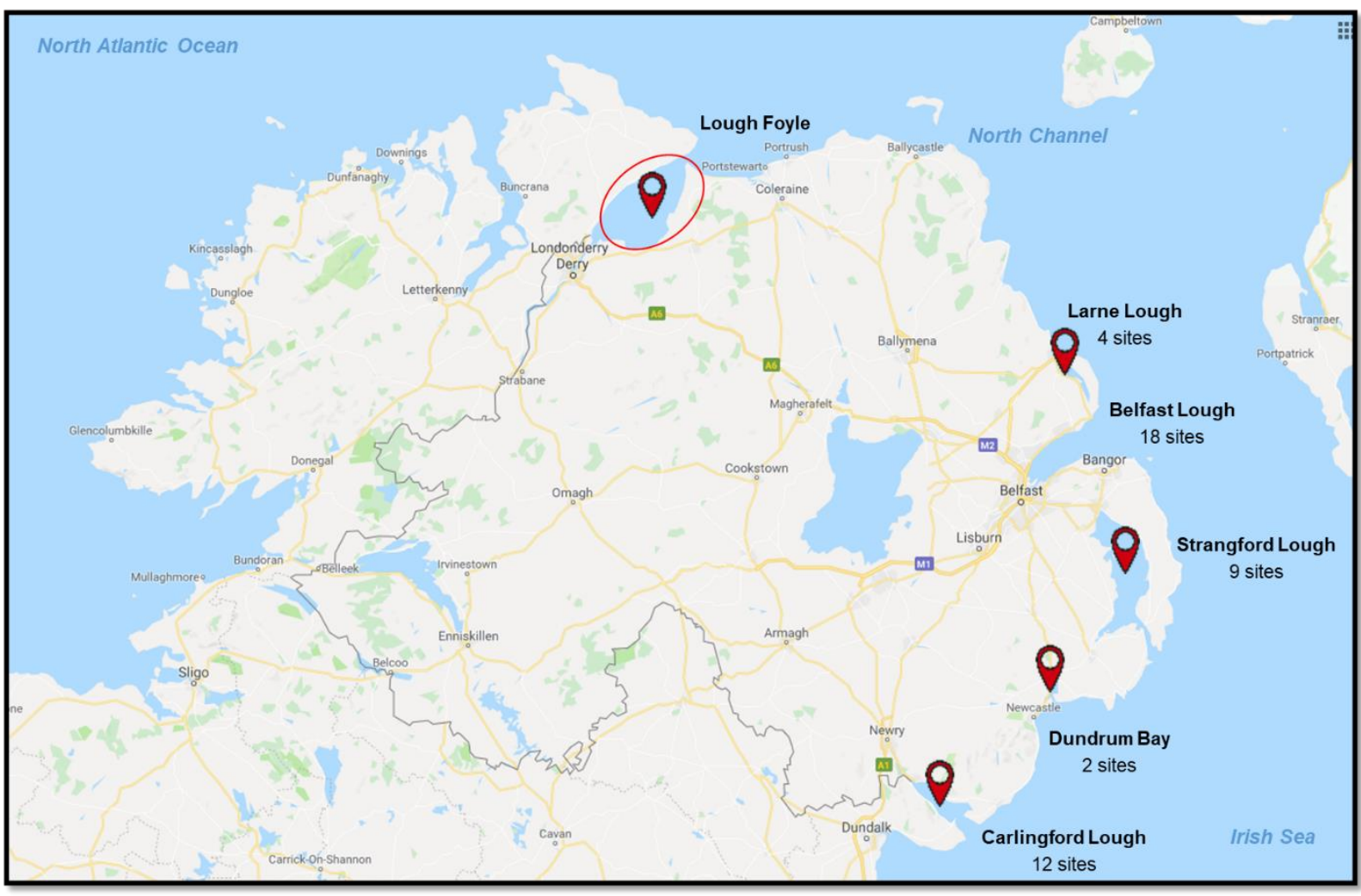

Figure 1: Shellfish production sites in NI.

The map of Northern Ireland (created using google maps) shows the water bodies where mollusc sites authorised for aquaculture production businesses are located in the region. The red circle indicates production in Lough Foyle which shares its border with the Republic of Ireland. Neither the UK or ROI governments has the ownership or power to regulate or licence shellfish production in this water body. 


\section{$\underline{2 \text { Trends in Shellfish Research }}$}

110 The barriers and facilitators to Shellfish Cultivation in the United Kingdom, Northern Ireland

111 and Ireland was initially discussed in the literature in 2003. These studies were conducted in 11215 different years over a 47 year time period (1970-2017) (Fig. 2a). Studies specific to the

113 United Kingdom, Northern Ireland and Ireland are relatively sparse and variable with the 114 majority (83\%) published from 2010 onwards (Fig. 2a). The literature is published over 14 115 different journals, predominately in the journal 'Aquaculture' (26\%), jointly followed by 116 Marine Pollution Bulletin (9\%), Preventative Veterinary Medicine (9\%), Journal of Sea 117 Research (9\%), and Parasitology International (9\%). The remaining journals had one publication each (4\%). The aims of the studies ranged from a review of the existing literature to investigations of the challenges and consequences of shellfish production. Within these publications a number of factors were cited which impact the success of the aquaculture industry. These factors could be categorised into Economic, Environmental, Technical, Welfare, Political and Consumer aspects (Table 2). The most commonly cited factors included regulations, management decisions, environmental welfare, weather conditions, consumer needs and water quality (Fig. 2b). There were a number of deficiencies and limitations within the scientific data for shellfish cultivation in NI. Firstly, data specific to NI describing the challenges and opportunities for shellfish cultivation is trivial. This is a limiting factor as many of the barriers and facilitators cited in the literature have regional differences and are not uniform to aquaculture sites across Ireland and the UK. Thus, in order to fully determine the challenges and opportunities specific to Northern Ireland, there is an urgent need to explore the factors which aqua culturists in this region experience during cultivation. 


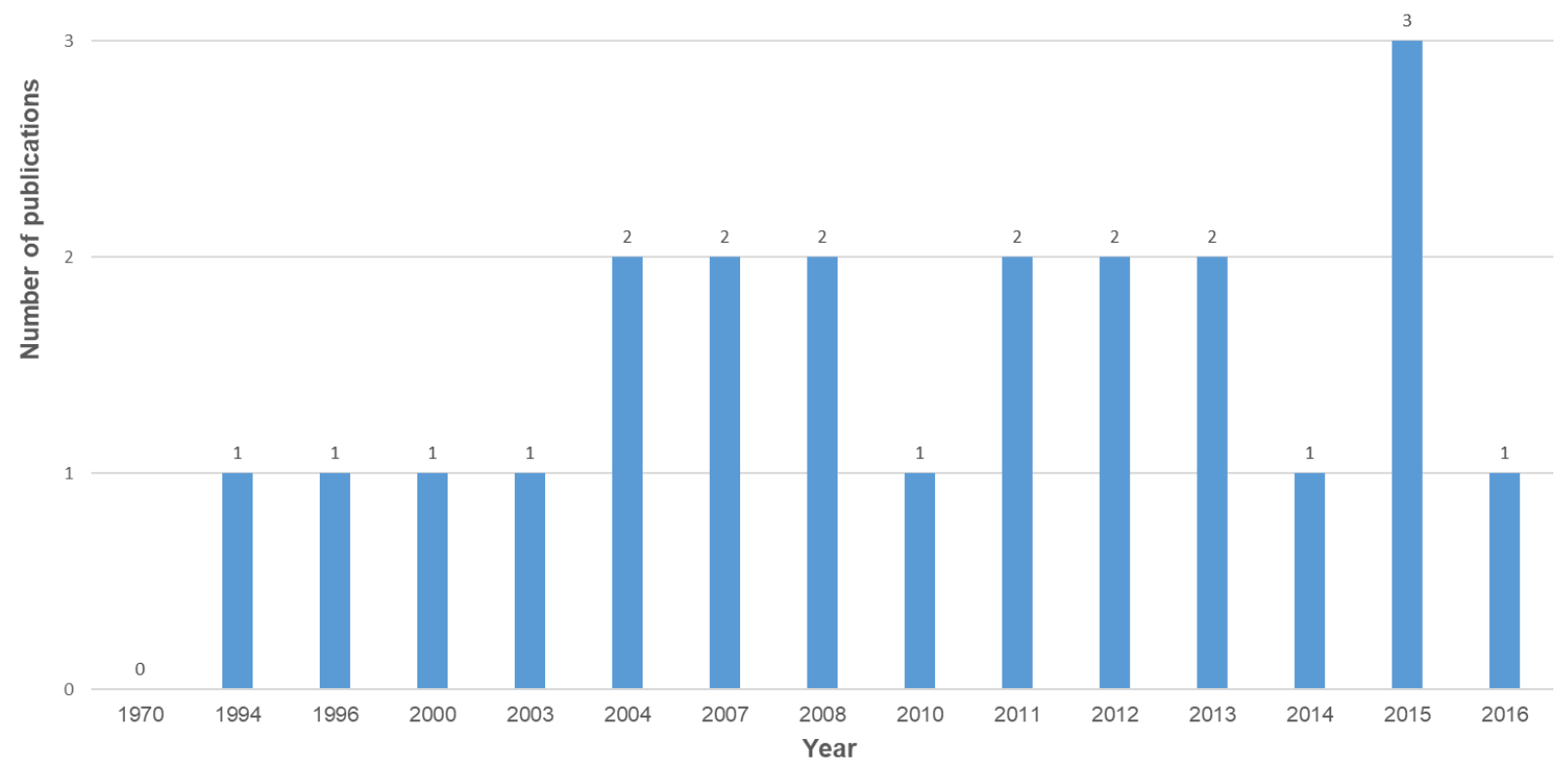

132 Figure 2a: The number of publications on the barriers and facilitators to shellfish 133 cultivation in United Kingdom and Ireland from 2003 to 2017.

134 The number scientific studies relating to the barriers and facilitators to shellfish cultivation in the United Kingdom,

135 Northern Ireland and Ireland.

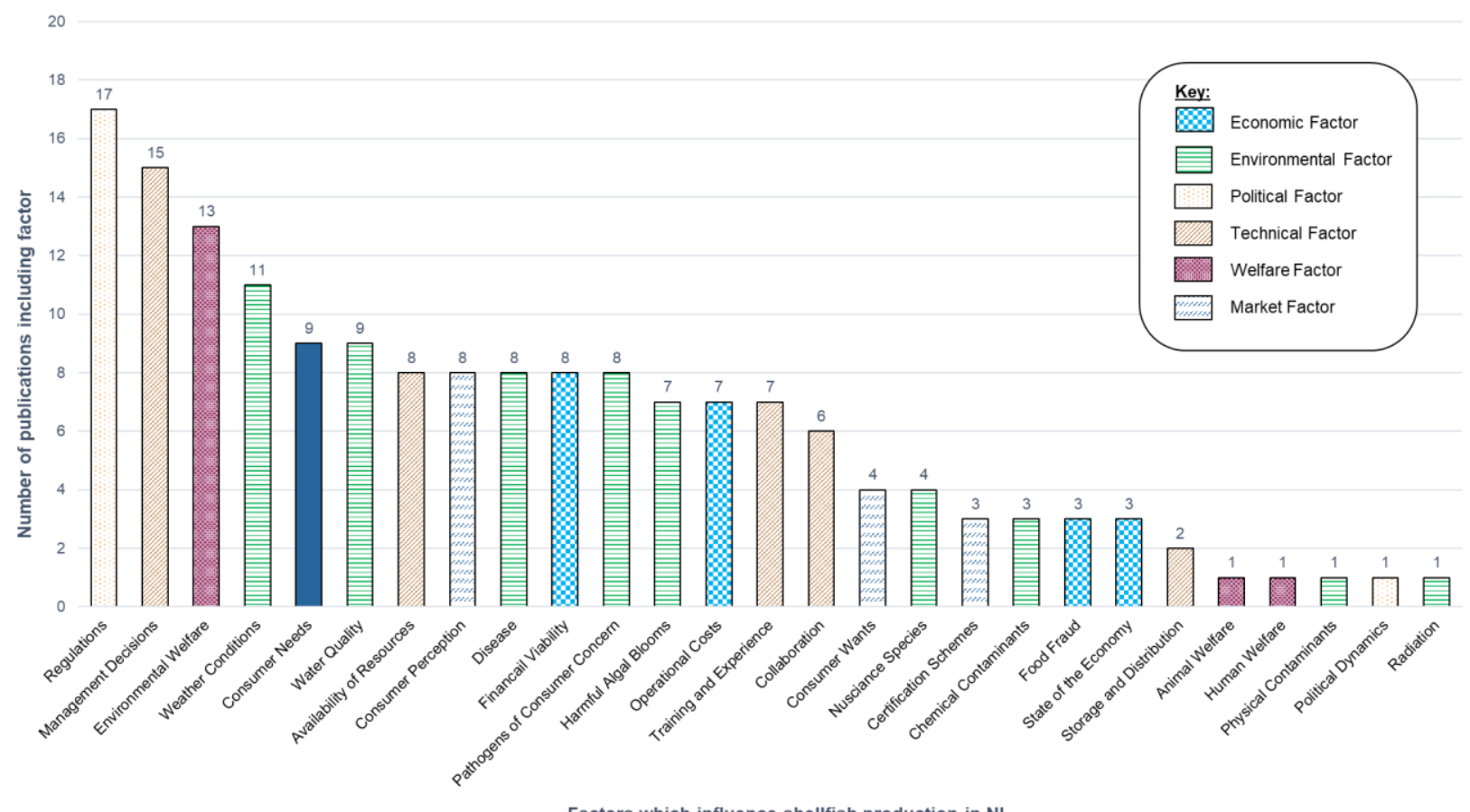


137 Figure 2b: The number of times each factor which influenced shellfish production in 138 Northern Ireland was identified in the literature.

139 The scientific literature has cited 27 different factors which influence shellfish cultivation in Northern Ireland.

140 The factors cited the most included regulations, management decisions and environmental welfare whilst animal

141 welfare, human welfare, physical contaminants, political dynamics and radiation were the least cited factors. 


\begin{tabular}{|c|c|c|c|c|}
\hline Category & Theme & $\begin{array}{l}\text { No. } \\
\text { papers } \\
\text { cited in }\end{array}$ & Illustrative Quote & References \\
\hline \multirow[t]{4}{*}{ Economic } & $\begin{array}{l}\text { Financial Viability } \\
\circ \quad \text { Income }\end{array}$ & 8 & $\begin{array}{l}\text { "Risks to social and economic sustainability result from low } \\
\text { financial viability of production systems and low resilience } \\
\text { to shocks" }\end{array}$ & $\begin{array}{l}\text { Jennings et al., 2016; Marquis et al., 2015; } \\
\text { Clegg et al., 2014; Nunes et al., 2011; } \\
\text { McCoy et at., 2015; Hannon et al., 2013; } \\
\text { Callaway et al., 2012; Oidtmann et al., 2011 }\end{array}$ \\
\hline & O Expenses & 7 & $\begin{array}{l}\text { "EU wide, the major costs are feed }(31 \%) \text {, stock }(18 \%) \text {, other } \\
\text { operational costs }(18 \%) \text { and labour costs }(15 \%) \text { but there is } \\
\text { considerable variation between sectors and countries" }\end{array}$ & $\begin{array}{l}\text { Jennings et al., 2016; Marquis et al., 2015; } \\
\text { McCoy et al., 2015; Clegg et al., 2014; } \\
\text { Hannon et al., 2013; Callaway et al.. 2012; } \\
\text { Oidtmann et al., 2011; }\end{array}$ \\
\hline & $\begin{array}{l}\text { State of the } \\
\text { Economy }\end{array}$ & 3 & $\begin{array}{l}\text { "The economic down turn has had a knock on effect on the } \\
\text { prices of marketable species both in Europe and } \\
\text { worldwide..." }\end{array}$ & $\begin{array}{l}\text { Jennings et al., 2016; Hannon et al., 2013; } \\
\text { Callaway et al., } 2012\end{array}$ \\
\hline & $\begin{array}{l}\text { Food Fraud } \\
\circ \quad 9 \text { sins of } \\
\text { Seafood }\end{array}$ & 3 & $\begin{array}{l}\text { "There are opportunities for deliberate misrepresentation } \\
\text { and mislabelling of product in most supply chains. If these } \\
\text { are taken, they can increase income and meet demand for } \\
\text { fish that cannot be met through legal routes" }\end{array}$ & $\begin{array}{l}\text { Crovato et al., 2017; Jennings et al., 2016; } \\
\text { Giangaspero et al., } 2009\end{array}$ \\
\hline \multirow[t]{2}{*}{ Environmental } & $\begin{array}{l}\text { Biological } \\
\circ \quad \text { Disease }\end{array}$ & 8 & $\begin{array}{l}\text { "...diseases are a key risk" } \\
\text { "[NI] Production benefits from a good health status with the } \\
\text { absence of notifiable diseases..." }\end{array}$ & $\begin{array}{l}\text { Jennings et al., 2016; Marquis et al., 2015; } \\
\text { Peeler et al., 2012; Callaway et al., 2012; } \\
\text { Nunes et al., 2011; Oidtmann et al., 2011; } \\
\text { Murray et al., 2012; Read and Fernandes, } \\
2003\end{array}$ \\
\hline & $\begin{array}{l}\circ \quad \text { Pathogens of } \\
\text { consumer concern }\end{array}$ & 8 & $\begin{array}{l}\text { "Bivalve molluscs are internationally recognised as a } \\
\text { potential vehicle for foodborne diseases especially when } \\
\text { consumed raw or improperly cooked" }\end{array}$ & $\begin{array}{l}\text { Crovato et al., 2017; Jennings et al., 2016; } \\
\text { Winterbourn et al,., 2016; Marquis et al., } \\
\text { 2015; Dabowski et al., 2014; Callaway et }\end{array}$ \\
\hline
\end{tabular}


- Water Quality

- Nuisance Species

- HAB's

- Weather Conditions

Chemical
9 "Bivalve molluscs are filter-feeding animals that may accumulate particles present in the surrounding water including viruses and pathogenic micro-organisms" "The seafood-harvesting areas (category A, B, C) are classified (by the regulations) according to an Escherichi coli indicator. This classification determines whether shellfish can be sent for direct consumption or must be treated previously to commercialisation."

"Most marine aquaculture enterprises are vulnerable to nuisance and harmful species, which can have direct negative effects on the cultured species to the extent that they kill entire stocks within days"

"Globally, harmful algal blooms (HABs) cause major environmental problems....and through the consumption of contaminated shellfish, can potentially impact human health"

"The health of both finfish and shellfish is heavily dependent on environmental conditions, such as temperature, salinity, oxygen solubility..."

"Aquaculture facilities are often located in areas which are likely to bear the brunt of climate change impacts"

"Chemicals in the environment, including pesticides, heavy metals and persistent organic pollutants can accumulate in fish and shellfish and can pose a public health issue" al., 2012; Giangaspero et al., 2009; Read and Fernandes, 2003

Crovato et al., 2017; Jennings et al., 2016; Winterbourn et al,., 2016; Marquis et al., 2015; Dabowski et al., 2014; Callaway et al., 2012; Nunes et al., 2011; Giangaspero et al., 2009; Read and Fernandes, 2003

Jennings et al., 2016; Tidbury et al., 2016; Callaway et al., 2012; Kraan, 2008

Crovato et al., 2017; Jennings et al., 2016; McCoy et al., 2015; Callaway et al., 2012; Nunes et al., 2011; Lopez-Rivera et al., 2010; Read and Fernandes, 2003

Jennings et al., 2016; O'Carroll et al., 2016; Marquis et al., 2015; Clegg et al., 2014; Dabrowski et al., 2014; Callaway et al., 2012; Murray et al., 2012; Peeler et al., 2012; Nunes et al., 2011; Giangaspero et al., 2009; Ferreira et al., 2008

Crovato et al., 2017; Jennings et al., 2016; Read and Fernandes, 2003 


\section{Physical}

Radionuclides "any foreign matter in food can cause injury or illness during human consumption"

"Monitoring programs have demonstrated that radioactivity in aquatic food is within safe limits and that exposure to members of the public from authorised discharges is well below the UK national and European limit"
Technical

Availability of

resources

- Sites

- Species

- Equipment

Management

Decisions

Training and

experience
8

"Production is controlled by the number and size of facilities, choice of cultured species"

"It has been suggested that the large scale growth of the industry has been constrained by a shortage of suitable sites and the ecological carrying capacity of existing sites."

15 "Inconsistent animal husbandry practices increases stress, slows growth and increases mortality."

"One of the key needs of the aquaculture industry is the implementation of effective management methods to ensure the sustainability, economic viability and minimization of negative impacts on both human and ecosystem wellbeing"

"Although member countries should work to the same level of standards, in reality this is not the case. This is a result of several factors: limited experience and training in surveillance or diagnostic methods for listed diseases, lack of knowledge of international trade standards, and lack of resources..."
Jennings et al., 2016

Jennings et al., 2016

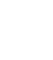


Research

"Information is sparse for the aquaculture sector"

"It is essential that such safeguards are formulated from the best available science and technology..."

"Validation of these models, however, remains critical if they are to be adopted..."

"To this end it is proposed that provision should be made for more and better research..."

6 "Some relevant data on...is held by individual enterprises, but little of this is publically available, nor is it collected systematically"

2 "As perishable food commodities, fish and fish products and the markets they support are rapidly affected by...breakdown of production or storage facilities or transport networks..."

Storage and

distribution
Crovato et al., 2017; Jennings et al., 2016; O'Carroll et al., 2016; Winterbourn et al., 2016; Forde et al., 2015; McCoy et al. 2015; Dabrowski et al., 2014; Dabrowski et al., 2013; Hannon et al., 2013; Callaway et al., 2012; Nunes et al., 2011; Oidtmann et al., 2011; Lopez-Rivera et al., 2010; Giangaspero et al., 2009; Kraan, 2008; Ferreira et al., 2008; Read and Fernandes, 2003

Forde et al., 2015; Hannon et al., 2013; Callaway et al., 2012; Oidtmann et al., 2011; Ferreira et al., 2008; Read and Fernandes, 2003

Crovato et al., 2017; Jennings et al., 2016

"In aquaculture, welfare is an issue throughout the life cycle as well as the point of slaughter. Stocking density, diet, feeding technique and management procedures all affect welfare prior to death. In part, welfare is a focus of aquaculture operations because it affects the health and flesh quality of fish"

Human

"Aquatic food production, relies on industries where Jennings et al., 2016 workers can be, and/or are exposed to higher risk of injury, death and human right abuses than in many other jobs" 
Environment aesthetic aspects to direct pollution problems." "However, the CBD also recognises that aquaculture may have positive effects on biodiversity..."
Tidbury et al., 2016; O'Carroll et al., 2016; Alexander et al., 2015; Forde et al., 2015; Marquis et al., 2015; Dabrowski et al.,, 2013; Callaway et al., 2012; Nunes et al., 2011; Murray et al., 2012; Oidtmann et al., 2011; Kraan, 2008; Ferreira et al., 2008; Read and Fernandes, 2003
Political

Regulations

- Legislation

- Inspection \& Monitoring

- Enforcement

Certification

Schemes

○ Voluntary

- Expensive

- Competitive advantage

Political Dynamics
17

"Regulation in this sector addresses registration of aquaculture production businesses (APB), aquatic animal health, managing the environmental impact of discharges, and planning and managing interactions with other users"

"The legislative framework must include a clear delineation of responsibilities and therefore accountability for the application of the statutory requirements"

"The regulatory framework is complex and extensive and this may be a barrier..."

"Monitoring programmes are in place to ensure effective regulation"

3 "Institutional measures such as Codes of Conduct and Codes of Best Practice have been and are being established at international, national and Aquaculture Producer Association level as mechanisms of self-regulation"

"Certified products tend to be more expensive, but suit buyers and consumers who want assurances and can afford to make a choice."

1 "Supply chains may be impacted by strikes, trade Jennings et al., 2016 restrictions or embargoes and political unrest"
Crovato et al, 2017; Jennings et al 2016; O'Carroll et al., 2016; Tidbury et al., 2016; Alexander et al., 2015; Forde et al., 2015; Clegg et al., 2014; Dabrowski et al., 2014; Dabrowski et al., 2013; Hannon et al., 2013; Callaway et al., 2012; Nunes et al., 2011; Oidtmann et al., 2011; Lopez-Rivera et al., 2010; Giangaspero et al., 2009; Ferreira et al., 2008; Read and Fernandes, 2003

Jennings et al., 2016; Ferreira et al., 2008; Read and Fernandes, 2003 


\section{Consumer}

Market Demand

- Consumer

Needs

- Consumer

Wants

Consumer

Perception

- Campaign

Groups

- Health scares

- Risk

communication
9 "Many other sources of nutrition are available, and 'sufficient' is usually treated as sufficient to meet demand" "To meet future demands...aquaculture production will need to more than double to 140 million tonnes by the year 2050."

$4 \quad$ "Demands for fish and shellfish as products are increasing" "The choices made by the average consumer are quite conservative"

"Consumers tended to respond to rises in fish prices by 'trading down' or reducing the amount they buy"

"Other barriers to eating fish included lack of knowledge about how to prepare them, lack of availability of fresh fish locally, preparation time, dislike of fishy smell and the need for meal planning"

8 "There is a significant commercial risk for companies when it is highlighted in the media and elsewhere that they are producing or trading aquatic foods that do not meet the expectations of consumers and society"

"Supply chains may be impacted by...health scares, consumer or supplier boycotts, campaign groups..."

"...implementation of risk communication activities is fundamental to promoting the responsible consumption of bivalve molluscs."
Jennings et al., 2016; Alexander et al., 2015; McCoy et al., 2015; Hannon et al., 2013; Dabrowski et al., 2013; Nunes et al., 2011; Oidtmann et al., 2011; Ferreira et al., 2008; Read and Fernandes, 2003

Crovato et al., 2017; Jennings et al., 2016; Alexander et al., 2015; Callaway et al., 2012

Crovato et al., 2017; Jennings at el., 2016; Alexander et al., 2015; McCoy et al., 2015; Dabrowski et al., 2014; Dabrowski et al., 2013; Nunes et al., 2011; Ferreira et al., 2008 
The barriers and facilitators to aquaculture production in Northern Ireland can be categorised into six distinct but linked categories. These include Economic, Environmental, Technical, Welfare, Political and Consumer Factors. Within each of these categories a number of key elements exist which act as a barrier, facilitator or both to aquaculture production. These are outlined within this section and illustrated in Figure 3.

\subsection{Economic}

Economic factors are those which influence the profitability of an aquaculture production business (APB). Economic factors include three key elements: Financial Viability, The State of the Economy and Food Fraud.

\subsubsection{Financial Viability}

In order to be profitable and facilitate shellfish production, income must exceed expenses. Income comes in the form of finance, i.e.: access to bank loans, grants, compensation or insurance schemes; sale of products and; savings. Expenses are any cost or outflow of money from the APB.

The primary economic return and facilitator for aquaculture production is the sale of its commodities. This is dependent on the retail price coupled with the quantity of sales. It should incorporate the cost or expenses required for production, (e.g. raw materials, labour, transportation etc.) whilst allowing a profitable return for the business. This price will be influenced by supply and demand, i.e. how willing and able the consumers are to purchase the commodity (consumer factors) and how the business is able to make available what the consumer wants (technical factors). A greater price can be commanded with greater market demand and provided this demand remains higher than supply. As an example, oyster herpes virus in France led to a decrease in the French supply and increased the demand for disease- 
free oysters. This allowed disease-free areas, such as NI, to capitalise on the increased demand (Peeler et al., 2012). Shellfish products from NI are perceived as a quality product attracting a high price. This is evident from the fact that although shellfish production has decreased substantially from 2010 to $2016(-165 \%)$ the value of production has actually increased 3\% (Table 1). This indicates a considerable increase in value (168\%) within a 6 year time frame.

Table 1: Production and value of the aquaculture sector in Northern Ireland

\begin{tabular}{|c|c|c|c|c|}
\hline & \multicolumn{2}{|c|}{2010} & \multicolumn{2}{|c|}{2016} \\
\hline & Tonnes & $£\left({ }^{\circ} 000\right)$ & Tonnes & $£\left({ }^{\circ} 000\right)$ \\
\hline Finfish & 1155 & 3100 & 1136 & 6300 \\
\hline Shellfish & 11081 & 7700 & 3468 & 7900 \\
\hline Both & 12236 & 10800 & 4604 & 14200 \\
\hline
\end{tabular}

Savings is another crucial facilitator of sustainable shellfish cultivation. This sector is subject to a range of current and emerging barriers to its production (discussed throughout this paper). The greater the level of savings a business can accumulate, the more resilient it will be to overcome such risks and thus the more likely it is to remain viable for the long-term (Jennings et al., 2016). Grants are non-payable funds gifted to an APB to facilitate production. In the European Union the European Maritime Fisheries Fund (EMFF) supports projects that deliver on sustainable economic growth in the sea fisheries and aquaculture sectors. EMFF funding available in NI is currently $€ 13.73 \mathrm{~m}$ plus a national allocation of $€ 4.58 \mathrm{~m}$ (Total: $€ 18.31 \mathrm{~m}$ ) (DAERA, 2018). Shellfish farmers can apply for $50 \%$ grant aid on the cost of aquaculture equipment through this fund. A review of the EMFF in the UK was carried out in 2014 and illustrated how funding is a driver of sustainable development boosting economically viable and competitive aquaculture businesses who can adapt to changing needs (Gov.uk. 2014). Nevertheless, this only provides a financial aid for equipment and represents a small contribution to the overall expenses of a business. A number of critical economic barriers in 
terms of income and expenses continue to exist for shellfish production within NI. Bank loans are a form of finance. However, banks are not keen to finance an APB because shellfish are a vulnerable species and therefore not a fixed asset (Bostock et al., 2010). Similarly, compensation schemes limit financial loss when damage or mortalities have occurred. However, there is currently no such scheme offered by the Government in England, Wales or NI (Oidtmann et al., 2011). The lack of investment to the aquaculture sector is not unique to this region. Poor access to credit has been described as a key constraint at the global level, particularly for small and medium scale aquaculture producers in both developing countries such as Egypt and developed countries such as the United States (Kleih et al., 2013; Bostock et al., 2010). In terms of expenses, the greater the expenditure of a business, the lower profits it generates. Jennings et al., (2016) described the major costs to aquaculture production, EU wide, as: feed (31\%), stock (18\%), operational (18\%) and labour costs $(15 \%)$ but stated there is considerable variation across sectors and countries. These statistics were not differentiated into finfish, shellfish or seaweed and thus are not directly transferable to shellfish cultivation. Other costs have included: securing a suitable site; conducting an environmental impact assessment; purchasing raw materials (e.g. equipment, species etc.); production losses; labour; mitigation and control measures; and transportation costs (DAERA, 2018; Jennings et al., 2016; Callaway et al., 2012). Research undertaken by Kleith et al., (2013) revealed lenders should be encouraged to develop more credit and saving products targeting the aquaculture sector, particularly small-medium enterprises (SME's). To facilitate this, a key requirement appears to be more emphasis on better financial management by aquaculture businesses; equipping APB's with the skills to fully articulate their ventures to funders; and improved information flows to reduce negative perceptions about the riskiness of aquaculture investments (Muir, 2005). 


\subsubsection{The State of the Economy}

215

216

217

218

219

220

221

222

223

224

225

226

227

228

229

230

231

The financial viability of a business is contingent on the state of the economy, i.e. the economic environment in a country or region. The condition is considered a facilitator to production when the economy is expanding and a barrier when it is in decline.

At present, an APB is facilitated by the fact the UK has a strong economy and claims one of the highest GPD's in the world, only behind Germany within Europe. It continues to have Foreign Direct Investment and jobs tend to be plentiful. In this state, consumers have a greater confidence to spend more which provides greater market opportunities and allows businesses to prosper. However, the state of the economy is dynamic and the economic conditions can change as a result of monetary policy decisions, a process known as the monetary policy transmission. If the economy declines consumers don't have excess income and tend to spend less. Consequently, this may force businesses to cut costs to maintain profits and act as a barrier to an APB. For example, the economic crisis which hit the UK in 2008-2009 reduced the purchasing power and attitude of consumers and forced companies to drop their prices or clear smaller volumes. As a result, many of the economically inefficient APB's collapsed. This had devastating effects on the shellfish farmers involved and the livelihoods and communities they supported. However, it has also resulted in a more efficient industry as the more proficient businesses survived and acquired the sites which collapsed (Jennings et al., 2016; STECF, 2013). In NI, the shellfish species cultivated are primarily exported. Thus, this industry also relies heavily on the state of the economy in the countries it supplies. It is therefore vital to be aware of economic trends in such countries in order to react ahead of any potential reductions in demand. The economic factors which affect the monetary policy transmission, and thus act as a barrier or a facilitator, include: the country's political situation, banking policies (interest rates and borrowing capacity), exchange rate, inflation and competition. The political position of a country (see political factors) can influence taxes and government spending within the 
region. Taxes are a direct payment for an $\mathrm{APB}$, and the businesses and consumers in the supply chain. Any change can affect the disposable income, consumer demand and asset value. In terms of government spending a greater level of spending often stimulates the economy and vice versa. Political decisions also have a role to play (discussed further under political factors). For example, the decision for the UK to leave the EU resulted in a drop in the GDP of the sterling. Banking policies can impact the ability of a business to attain the necessary funds to become established and sustainable. In particular, the aquaculture industry is associated with a high capital cost at the onset or during development work and a delayed period of production before any economic return. Moreover, aquaculture in NI is characterised by small-medium enterprises (SMEs) which rely heavily on access to loans from banks or other financial institutions as a source of funding. Worryingly, it has been cited that aquaculture has not been recognised as a viable business venture for such funding. When loans are attained, interest rates become an additional expenditure and any changes to interest rates can affect the total expenses for a company with debt, or, the extent of savings for a profitable business. Exchange rates are another concern, particularly as importing and exporting materials and commodities is a key characteristic of shellfish cultivation in NI. A change in exchange rates may affect the cost or return of an item and affect how a company should pay or receive money from its international suppliers and buyers. Inflation is another economic factor. Inflation is the rate at which prices within the economy are increasing and causes increases in the businesses expenses, including rent, utilities and cost of materials used in production. This may force an APB to raise the cost of their commodities in order to maintain profits. Concurrently, inflation can reduce the purchasing power of consumers (unless employers increase wages based on the level of inflation) as demand of goods is directly dependent on its availability and price. Moreover, competitive factors such as imitation products and price wars can have consequences to the price, sale and thus profitability of a business. These elements under the state of the economy 
exist for aquaculture production businesses worldwide. Ultimately, it is vital to consider and understand the economic environment and the factors which influence it or this may prove to be a major constraint to the profitability and growth of this sector (Habrey and Evans, 2016).

\subsubsection{Food Fraud}

Food fraud is an intentional act for economic gain and thus introduces another economic barrier into the food supply chain. In particular, aquatic products have been described as extremely vulnerable to fraudulent activities. This is because they are highly traded and often involve food passing through an internationalised and complex supply chain. Moreover, it includes: a very diverse range of species, often closely related and visually similar; production by aquaculture or the wild fisheries; may involve processing where appearance or flavour are modified; and, can involve the use of common names on sales notes and labels. This creates opportunities for an increase in income or supply that cannot be achieved through legal routes (Jennings et al., 2016). The types of fraud which can occur in the seafood supply chain have been termed the ' 9 sins of seafood', namely species substitution, fishery substitution, chain of custody abuse, species adulteration, illegal, unreported and unregulated (IUU) substitution, catch method fraud, undeclared product extension, modern day slavery and animal welfare (Elliott, 2014). In terms of shellfish cultivation in NI, the industry predominately involves the are minimal. In addition, if shellfish are stressed this negatively affects the productivity, quality and price of the shellfish. Therefore, animal welfare concerns are not warranted. However, opportunities for fishery substitution, catch method fraud and IUU substitution do exist. Fishery substitution is the substitution of a product from a fishery with an inferior reputation to a superior reputation. It can be carried out by aqua-culturists who mislabel the farming site, e.g. labelling shellfish from a Class $\mathrm{C}$ site as a Class A site to increase market opportunities, 
but, it is more commonly associated with distributors, middlemen and food service companies. For example, most of the oyster cultivation in NI is exported to French markets. There, food service companies may label the oysters as French to receive a greater market. IUU substitution includes shellfish which have been farmed in areas closed for harvest, the use of unlicensed vessels or farms, or illegal movements of shellfish. For example, shellfish from a disease area cannot be legally moved to a disease free area. However it is suspected an illegal movement of oysters from West Galway to Lough Foyle occurred in 2005. Consequently, Bonamia ostrae was introduced into Lough Foyle and meant the area lost its disease free status. Catch method fraud involves the mislabelling or advertising of the type of production or harvesting method to increase financial return. The consumer views 'wild' species as a superior standard than farmed species and thus this fraud allows greater financial return particularly outside of their wild season and when in lower supply (Fox et al., 2018; Jacquet and Pauly, 2008). Food fraud has vexed the food industry globally and throughout history. It is not known conclusively how widespread food fraud is because those who commit the act seek to avoid detection (Johnson, 2014). However, it acts as a barrier in the supply chain as it has consequences to: animal health and productivity; traceability and food safety; consumer confidence; meeting legal requirements; ensuring fair competition among producers and processors; allowing consumers to receive what they pay for; and ensuring the benefits and risks of products are known (Jennings et al., 2016). In order to tackle food fraud, the opportunities must be reduced through vulnerability analysis critical control point (VACCP) principles. This will make fraudulent commodities much harder to market and reduce the incentive (Fox et al., 2018; Heylar et al., 2014).

\subsection{Environmental}

Bivalve molluscs are sessile creatures. Although they appear robust they are perishable when harvested and prone to temperature stress and physical shocks. They are also filter feeders, 
feeding from the surrounding water. As a result molluscs are highly dependent on their natural environment and may greatly concentrate certain contaminants (Jennings et al., 2016). This coupled with the fact bivalves are characteristically tender, easily digested and are often eaten raw or only lightly cooked poses a direct threat to human health (Crovato et al., 2017; Murchie et al., 2015; Lees, 2000). It is therefore crucial to consider environmental features to ensure a safe and successful industry. These features can be categorised into biological, chemical and physical factors.

\subsubsection{Biological Factors}

Biological factors are those relating to life or living organisms. They can either act as both a facilitator and barrier to shellfish cultivation. The biological factors include: Weather and Climate Change; Water Quality; Disease; Pathogens of Consumer Concern and Harmful Algal Blooms.

\subsubsection{Weather Conditions and Climate Change}

Bivalve molluscs are poikilothermic organisms. Their metabolic rate, energy requirements and growth potential are highly dependent on environmental conditions such as temperature, salinity, wave regime, storm frequency or sea level (Callaway et al., 2012; Murray et al., 2012). In addition, bivalve farming may rely on wild spat and broodstock for stock, plankton for food and water quality for health, all of which are impacted by climate. In NI, the weather and temperature regime is generally within the optimum range for shellfish production and may actually facilitate spat fall, growth rates, food conversion efficiencies, growing seasons, range expansion and use of new areas (FAO, 2016; De Silva and Soto, 2009). However, there have been a number of extreme weather events which are a barrier to production. For example, low pressure, tidal surges and record wave heights recorded in Ireland and UK during December 
2016), whilst flooding events have increased pressure on sewage structures and resulted in increased microbial load of coastal and harvesting waters (Winterbourn et al., 2016). In particular, bivalve larvae naturally exhibit high mortality rate (>98\% in the wild) during their transitional phase from free swimming larvae juveniles. Thus any additional stress from the weather conditions can significantly reduce the number of individuals recruited (Callaway et al., 2012). As a result, weather conditions, particularly seasonal differences, can have a positive or negative effect on the growth of bivalves and may be largely responsible for any differences in growth between sites and other production regions, e.g. France and China.

The reliance of bivalve molluscs on the weather conditions is particularly worrying as the threat of climate change looms. Climate change is the large scale, long-term shift in global or regional climate patterns. In Ireland, this change is predicted to incorporate longer growing seasons, milder winters, a further $1.5^{\circ} \mathrm{C}$ increase in January temperatures and a $2.5^{\circ} \mathrm{C}$ increase in July temperatures by 2050 . The annual precipitation is to remain relatively unchanged, but with an increase of rainfall predicted in the winter by $10-25 \%$ and a reduction in summer precipitation by $25-40 \%$ (Dunne et al., 2009). These changes are not expected to be uniform across the Island of Ireland resulting in regional differences. Other patterns, including: increased $\mathrm{pH}$; sea level rise; extreme climatic events; and modified ocean circulation patterns, monsoon cycles and hydrological regimes have been described (Doubleday et al., 2013; De Silva and Sotto, 2009; Handisyde et al., 2006). These environmental changes are associated with barriers to shellfish production, including: stress; increases in invasive species, pests and disease (Bock et al., 2011; Burgiel and Muir, 2010; Halpern et al., 2008; Ramsay et al., 2008; Coutts and Forrest, 2007; Thompson and MacNair, 2004; Byers et al., 2002; Stachowicz et al., 2002); changes in farm husbandry practices (e.g. cleaning of infrastructure); altered species physiology (e.g. changes in growth rate and development); changing trends and distribution of toxins (e.g. introduction of Tetrodoxin) (Turner et al., 2015; Baker-Austin et al., 2013); impaired farm infrastructure 
and escapees (Callaway et al., 2012); diminished sustainability of current farming locations and; changes to day to day farm operations (Tewabe, 2015; Gilbert et al., 2014; Safefood 2014; Doubleday et al., 2013; Callaway et al., 2012; De Silva, 2012; Murray et al., 2012; Karvonen et al., 2010; Cochrane et al., 2009; Hobday et al., 2008; Brander 2007; Handisyde et al., 2006; Focardi et al., 2005). Climate change is also predicted to impact negatively upon the wild fisheries and its supply of feed and seed to the aquaculture industry. Thus, a heavier reliance on hatchery produced seed, selective species or changes to the species cultivated is predicted for the future (FAO, 2016; Callaway et al., 2012; Cooley and Doney, 2009). Conversely, new opportunities may arise by shifts and changes in wild stocks in response to climate change, i.e. greater demand for aquaculture as wild fishery production declines and hatching shellfish for restocking wild populations (Callaway et al., 2012). To date, there has been limited data to substantiate that aquaculture has suffered from climate change (Jennings et al., 2016; Barange et al., 2014; Cheung et al., 2010). Consequently, it has been difficult to differentiate climate change effects from natural environmental variability and the pace of technological development.

In NI, Ferreira et al., (2008) developed an ecosystem model (SMILE) which was used to predict the effects of climate change on aquaculture. This model indicates that an increase in water temperature would reduce aquaculture productivity and the mean weight and length of individuals, particularly for blue mussels. An increase of $1^{\circ} \mathrm{C}$, as proposed by DAERA fisheries for NI, would lead to an approximate $50 \%$ reduction in mussel production and less than $8 \%$ in Pacific oyster production. An increase of $4^{0} \mathrm{C}$, the maximum increase predicted by the year 2100 by the UN Intergovernmental Panel on Climate change, would result in a reduction of $70 \%$ in mussel production and less than $8 \%$ in Pacific oyster production. The model also indicated changes to nutrient inputs due to modifications in the hydrological regime and land use of the catchment. It is therefore important to establish and monitor the critical limits for 
environmental conditions and assign mitigation and control to counteract undesirable conditions. Changing weather patterns is not a situation unique to NI (Bostock et al., 2010).

Development Goals (United Nations, 2015). Climate change is predicted to have the greatest consequences in higher tropic regions and developing countries, where a large proportion of aquaculture production occurs (Corlett, 2012). Research and adaption will be vital for sustainable production in these regions.

\subsubsection{Water Quality}

Water quality is a measure of the condition of the water relative to the requirements of shellfish production. Good water quality is important to facilitate the growth of high quality and safe shellfish, whilst poor water quality acts as a barrier to production (DAERA, 2018; Dabrowski et al., 2014). EC Regulation (2004) classifies water quality of shellfish harvesting sites into one of three categories (A, B or C) based on the concentration of the faecal indicator organism Escherichia coli, present in shellfish flesh. The latest classification in February 2018 revealed only one classified shellfish bed had an A classification; thirty had a class B; whilst five had a class $\mathrm{C}$. The remaining four sites experienced seasonal changes, moving between a B and C classification (FSA, 2018). This classification system defines the level of post-harvest treatment prior to sale for human consumption (Crovato et al., 2017). Thus, only one site is capable of sale for direct human consumption without further on-growing or purification (Table 3). The monitoring for the presence of phytoplankton, marine biotoxins and chemical contaminants in samples of shellfish flesh is also undertaken. Any deterioration in water quality or site can result in an increase in ambient levels of opportunistic pathogens (e.g. Trichodina sp.) and promote secondary infection by bacteria (Callaway et al., 2012). Consequently, the harvesting site may drop a classification level which has economic repercussions due to 
increased treatment and production time and reduced reputation and market demand for the

414 shellfish. Water bodies can be impacted by pollution and reduced quality from various sources,

415 including run-off from agricultural land or discharges from sewage treatment works (DAERA,

416 2018). Other water users pose the greatest threat to water quality (Winterbourn et al., 2016).

417 This is evident during summer when there is greater effluent loading into water bodies located near popular tourist destinations (Dabrowski et al., 2014). Similarly, at times of increased runoff, e.g. flooding events, the water body suffers from increased turbidity, nutrient loads and contaminant loads to the near shore environment as a result of sewage overflows (Winterbourn et al., 2016; Callaway et al., 2012; Kay, 2008). Nitrogen-related pollution of coastal waters has caused widespread hypoxia and anoxia, habitat degradation, alteration of food-web structure and loss of biodiversity (Callaway et al., 2012; Howarth, 2008). The situation will only worsen as population, industry and climate changes grow.

\begin{tabular}{|c|c|c|}
\hline $\begin{array}{c}\text { Bed } \\
\text { Classification }\end{array}$ & $\begin{array}{c}\text { E. Coli } \\
\text { presence } / 100 \mathrm{~g} \\
\text { flesh }\end{array}$ & Effect upon the bed \\
\hline A & 230 or less & $\begin{array}{l}\text { Live bivalve molluscs can be harvested and marketed } \\
\text { directly for human consumption }\end{array}$ \\
\hline B & $231-18000$ & $\begin{array}{l}\text { An area which live bivalve molluscs can be gathered } \\
\text { but only placed on the market for human consumption: } \\
\text { a) After treatment in a purification centre or after } \\
\text { relaying (followed, where necessary, by treatment } \\
\text { in a purification centre); or, } \\
\text { b) After heat treatment by an approved process in an } \\
\text { approved establishment. }\end{array}$ \\
\hline $\mathrm{C}$ & $18001-46000$ & $\begin{array}{l}\text { An area from which live bivalve molluscs can be } \\
\text { gathered only after: } \\
\text { a) A relaying period of at least } 2 \text { months, followed, } \\
\text { where necessary by treatment in a purification } \\
\text { centre; or } \\
\text { b) Heat treatment by an approved process in an } \\
\text { approved establishment } \\
\text { No shellfish can be placed on the market of such beds. }\end{array}$ \\
\hline
\end{tabular}




\subsubsection{Disease}

429

Disease is the single biggest risk to the maintenance and growth of aquaculture production

430 (Carnegie, et al., 2016; Jennings et al., 2016; Marquis et al., 2015; Murray et al., 2012;

Oidtmann et al., 2011). At present, NI has a high health status and it is declared free of a number

of shellfish diseases. This provides the region with a unique marketing opportunity to capitalise on the demand for disease free oysters. However, notifiable diseases are known to be present: Bonamia ostrea in Lough Foyle and Strangford Lough, Oyster Herpes Virus (OsHV-1- $\mu$ Var) (only Lough Larne is free) and as of 2017, Marteillia Refringens in Belfast Lough and Dundrum bay (DAERA, 2018). These diseases can have huge economic repercussions to these areas through mortality and movement restrictions (IFREMER, 2017; DEFRA, 2014; Murray et al., 2012; Arzul et al., 2011; Oidtmann et al., 2011).

Bonamia ostreae is an intracellular haplosporidian protozoan parasite which causes Bonamiosis, a lethal infection to the haemocytes of flat oysters, Ostrea edulis, and the native oyster. An infected oyster typically appears normal but clinical signs may occur up to 5 months after infection Worldwide, the prevalence of Bonamia ostreae in infected populations is variable $(0-80 \%)$ (OIE, 2018). Whilst in NI, they are typically $1-3 \%$ in wild areas and $20-30 \%$ in farmed areas with relatively low levels of mortality (IFREMER, 2017). Epidemiological studies indicate seasonal, size, age, stress, and environmental conditions all impact on the prevalence and intensity of infection observed (OIE, 2018; DEFRA, 2014; Flannery et al., 2014). Typically, the parasite is active at temperatures of $12^{\circ} \mathrm{C}$ and higher salinities, although warmer temperatures may also increase disease outbreaks (OIE, 2018; DEFRA, 2014; Murray et al., 2012). It has been associated with winter mortality in France and Ireland. In NI, the host for Bonamia is the native oyster, whilst the Pacific oyster has been described as a carrier of the 
disease (Murray et al., 2012; Lynch et al., 2010). There is no known treatment for Bonamiosis

452

453

454

455

456

457

458

459

460

461

462

463

464

465

466

467

468

469

470

471

472

473

474

475

and the only effective control is to prevent the introduction of the disease through restricting live movements from infected areas. This can introduce barriers to importing seed and exporting finished bivalves to a disease free region(DEFRA, 2014).

Martelia refringens is another protozoan parasite which causes Marteiloisos in Blue mussels (Mytilus edulis) (40-100\% mortality) and Native and Pacific oysters (80-90\% mortality) (OIE, 2017). It requires temperatures in excess of $17^{\circ} \mathrm{C}$ for sporulation and transmission (OIE, 2017) and survives best at reduced salinities (Murray et al., 2012; Robelo and Figueras, 1995). M. Refringens was first detected in NI in 2017 during routine testing in Belfast Lough and Dundrum Bay (DAERA, 2018). There was no clinical signs of disease in the Blue mussels, but, the infected area is under confirmed designation notice and movement restrictions are in place (DAERA, 2018; OIE, 2017). Marteiloiosis evolves concurrently with B. osteae but displays a different dynamics pattern, probably due to the fact both diseases deplete the host's resources and thus affect the development of the other parasite during co-infection (Arzul et al., 2017; IFREMER, 2017). In combination with B. ostrease, $M$. refringens has been associated with $>90 \%$ decline in $O$. edulis population in France illustrating its devastating effects in a region (Murray et al., 2012; Arzul et al., 2011) Recent phylogeny work on these parasites suggest that Marteilia refringens should be considered as two distinct species, called types $\mathrm{M}$ and $\mathrm{O}$ (IFREMER, 2017). Marteilia refringens type $\mathrm{M}$ also known as $M$. pararefringens, infects Mytilus edulis in the UK, Norway, Sweden and NI but is not present in flat oysters farmed in the same zones (IFREMER, 2017; Murray et al., 2012). Marteilia refingines 'O-type' is genetically and biologically distinct from 'M-type' and has not yet been recorded in NI.

Oyster Herpes Virus is a virulent disease of both the Pacific oyster, Crassostrea gigas and native oysters (Degremont et al., 2013). It has been associated with the sudden and high 
mortality of $C$. gigas (up to $100 \%$ in a few days) reared in France, Ireland and England, 477 particularly in the summers of 2008 and 2009 (Murray et al., 2012; Oidtmann et al., 2011; Renault, 2011; Peeler et al., 2010; Segarra et al., 2010). Though, the cause of mortality events in $C$. gigas are believed to be multifactorial with OsHV-1 infection (with OsHV-1 $\mu$ Var now predominating) a necessary but not sufficient cause (Clegg et al., 2014; Samain, 2011). Other suspected risk factors include viral load of the bay (Clegg et al., 2014; Garcia et al., 2011; Schikorski et al., 2011; Sauvage et al., 2009; Pepin et al., 2008); a sudden change or increase in temperature (Clegg et al., 2014; Degremont et al., 2010; Peeler et al., 2012) husbandry and farm management practices such as introduction of possibly infected spat (Clegg et al., 2014; EFSA, 2010; Samain and McCombie, 2010), the movement and mixing of populations, age and condition of oysters when first infected and no prior exposure of the seed or the related broodstock to the virus (Clegg et al., 2014; Pernet et al., 2012; Garcia et al., 2011; EFSA, 2010; Huvet et al., 2010; Sauvage et al., 2009; Degremont et al., 2007). In particular, the European Food Safety Authority (EFSA, 2010) noted that no outbreaks have been reported when the water temperature was below $16^{\circ} \mathrm{C}$. Oyster herpes virus is not yet a listed disease but it is considered of relevance and notifiable in NI as it was associated with high levels of mortality of both adult (25\%) and larval (mean 55\%) Pacific Oysters in Ireland during May to August 2009 (Clegg et al., 2014; Murray et al., 2012; Peeler et al., 2012; Malham et al., 2009). Since 2009, this mortality has been linked to the presence of OsHV-1 $\mu$ Var (Clegg et al., 2014; Murray et al., 2012; EFSA, 2010; Segarra et al., 2010). Larne Lough is the only disease free area in this region and an ongoing surveillance and sampling program is required to retain this disease free status. The virus has not been detected in Dundrum Bay but it has been removed from the surveillance program due to an industry request stating sourcing and operational difficulties (DAERA, 2013).There is a number of other diseases associated with shellfish cultivation in NI. In 2015, Haplosporidium costale was detected in C. gigas in UK and 
Mikrocytos mimcus was reported in two small farms, although, it has never been seen again (IFREMER, 2017). Surveillance is no longer implemented for M. mimicus as the infection causes some specific heavy clinical signs sufficient for detection. This parasite is associated with very low temperatures (IFREMER, 2017). In Ireland, the bacterium Vibrio hemicentrotti is screened as it was described during mussel mortality events in France. However, at the 2017 Annual meeting of NRLs for Mollusc Disease it was stated that additional work carried out in 2016 on the mussel mortality samples concluded that hemicentroti was a false alarm for mussel mortality in France; after full sequencing they found that it was actually Vibrio splendidus present (IFREMER, 2017). This NRL meeting also commented on the trends in shellfish disease, stating that the mortality levels in the past couple of years has been very low with only two events investigated in 2016. These events involved Pacific oyster, $C$. gigas, but the origin or the aetiological agent responsible for the mortality was unknown (likely environmental). It was also commented that there has been no conclusive explanation found to explain the significant decrease in mortality except differences in rain (IFREMER, 2017). Thus, disease still poses uncertainty to aquaculture especially as the industry is predicted to grow further in response to plateauing wild stocks. This growth is likely to be accompanied with intensified systems, new cultured species, expansion into new geographical areas and the development of new systems. Historically, major aquatic disease incidents throughout the globe has occurred in parallel with such developments (see examples in Oidtmann et al., 2011). Therefore, the introduction and spread of disease must be mitigated. There is a number of typical routes for disease into a shellfish harvesting site. The principle route involves the movement of waters, fomites, live vectors or aquatic animal products contaminated with disease (Murray et al., 2012; Dube et al., 2011; Oidtmann et al., 2011; Brown et al., 2006; Keeling and Eames, 2005). Other routes have been suggested. These include infection from lorries which carry live shellfish (although these enter empty so risk should be low if disinfection is carried out), import of 
pathogens within ballast water and shellfish attached to hulls during shipping and ornamental

527 fish trade (Murray et al., 2012). Pathogens may also be transported naturally due to water currents or wild vector species from zones of infection in adjacent territories, depending on their survival in seawater (Jennings et al., 2016; Murray et al., 2012; Bridges et al., 2007). In NI, the small isolated nature of the bivalve farming industry may restrict pathogens becoming more than a local problem. However, the presence of a number of farms in the one lough may mean that all sites within that lough are at risk of being infected as a result of management decisions made by a near-by farm (Murray et al., 2012). Once established pathogen eradication may be impossible (Oidtmann et al., 2011) and the intensity of the disease will increase dependent on the size of the population (Jennings et al., 2016; Murray et al., 2012; Bridges et al., 2007). Ultimately, disease has proved to be a major constraint to efficient production throughout global aquaculture systems. New disease problems are emerging. Continued vigilance and solution development is vital (Bostock et al., 2010).

\subsubsection{Pathogens of consumer concern}

540 Bivalve molluscs are filter feeders that can greatly concentrate protists, bacteria and viruses from their surrounding environment, particularly in areas impacted by sewage. As these species are often eaten raw, they pose a public health risk if the pathogens are not cleared or inactivated by the bivalves (Crovato et al., 2017; Jennings et al., 2016; Dabrowski et al., 2014). To ensure consumer safety, shellfish harvesting sites are subject to a monitoring program. Any site above safe limits will be closed down temporarily or long term posing a direct barrier to production (Marquis et al., 2015). Despite these controls, a number of outbreaks of human pathogenic viruses associated with bivalve shellfish continue to occur. In the EU, shellfish were responsible for $8.1 \%$ of strong evidence outbreaks and $2.3 \%$ of weak evidence outbreaks

549 (EFSA and ECDC, 2015). This has repercussions to the reputation and profitability of the farmer and industry. According to the EFSA (2015) norovirus was the predominant cause. 
551 Other pathogens of concern include: pathogenic protists, such as Cryptospordium spp. and the microsporidian Enterocytozoon bienesusi; members of the bacterial genus Vibrio; and viruses location factors (Jennings et al., 2016; Lowther et al., 2012; Le Guyader et al., 2010).

555 Norovirus is a single stranded RNA virus and is recognised as the largest aetiology linked pathogen group found in bivalve molluscs in Europe (Jennings et al., 2016; Winterbourn et al., 2016; Dabrowski et al., 2014; Lees, 2000). It is shed in great quantities by infected individuals, is present in high copy numbers in sewage waste, has a relatively low infectious dose, is environmentally stable, can mutate rapidly and is only slowly removed from shellfish by commercial depuration practices (Jennings et al., 2016). Consequently, norovirus is a persistent and significant shellfish-associated human pathogen causing outbreaks of acute gastroenteritis to people of all ages (Winterbourn et al., 2016).Shellfish are at particular risk during periods of heavy rainfall or snow meltwater when tertiary water treatment works are passed and effluent is discharged in a highly contaminated state. A systematic analysis of norovirus contamination in commercial oyster sites in the UK revealed that norovirus is highly prevalent, present at all sites with $76.2 \%$ of 844 samples positive (Jennings et al., 2016). Worryingly, these outbreaks have occurred when shellfish are compliant with E.coli standards (Dabrowski et al., 2014). This is because E. coli and norovirus can originate from different sources, are susceptible to different stresses and accumulate differently in shellfish (Winterbourn et al., 2016). Moreover, depuration methods that are effective against bacteria of faecal origin do not ensure the elimination of certain species of Vibrio or enteric viruses in the product (Crovato et al., 2017; Suffredini et al., 2014). It is therefore unsurprising that The Shellfish Association of Great Britain has seen an increase in the number of incidents of norovirus associated with

574 bivalves with current estimates for the UK population revealing 1 in 219 individuals are 575 infected each year, with gross underreporting of clinical cases suggested (Jennings et al., 2016). 
576 This warrants the need for a greater research effort, innovative technology and education and 577 training in order to overcome the threat from human pathogens.

578 There is increasing evidence of other viral pathogens linked to bivalve shellfish (Jennings et 579 al., 2016). Hepatitis A virus (HAV) is an established human pathogen which infects the 580 liver. It was responsible for the largest ever shellfish associated food-borne outbreak in history, affecting almost 300,000 people in the late 1980's (Potasman et al., 2002). The virus continues to cause approximately 1.5 million cases annually (Jennings et al., 2016). Several characteristics of HAV make it a significant shellfish pathogen: it is relatively stable in the environment, it can remain in shellfish matrices for long periods and it is only slowly removed from shellfish by depuration practices (Jennings et al., 2016). Hepatitis E virus (HEV) is a single stranded RNA virus which causes human infections via the faecal-oral route. Available epidemiological evidence for Western Europe indicates that the virus is responsible for around 5\% of cases of acute hepatitis and there is evidence of a large increase in reported cases in the UK in the last decade (Jennings et al., 2010). These pathogens are highly prevalent in swine wastewater and manure (McCreary et al., 2008) and can enter water courses and bio-accumulate in bivalve molluscs. However the evidence for HEV in shellfish is not conclusive (Grodzki et al., 2014).

Bacteria of the genus Vibrio are another pathogen responsible for severe infections in humans and animals. These are gram-negative bacteria which inhabit surface waters at coastal and estuarine sites and are responsible for a number of severe infections in humans and animals (Vezzulli et al., 2013). Only two Vibrio species, Vibrio vulnificus and Vibrio parahaemolyticus, are significant human pathogens that can occur in aquatic food (BakerAustin et al. 2009, 2010; Dechet et al. 2008; Altekruse et al. 2000). Vibrio cholerae is also a food pathogen, but it is rarely associated with seafood from the UK (Baker-Austin et al., 2009). The Vibrio species grow preferentially in warm $\left(>15^{\circ} \mathrm{C}\right)$ and low-salinity $(<25 \mathrm{ppt}$ 
$601 \mathrm{NaCl}$ ) seawater (Baker-Austin et al. 2010, 2013). The number of $V$. vulnificus and $V$.

602

603

604

605

606

607

608

609

610

611

612

613

614

615

616

617

618

619

620

621

622

623

624

625

parahaemolyticus infections is steadily increasing due to climate change and the associated

warming of low salinity marine environments (Lindgren et al., 2012; Burrows et al., 2011;

Martinez-Urtaza et al. 2010). Surveillance and monitoring of these infections are poor and disease burden of Vibrios from shellfish consumption is likely underestimated (Jennings et al., 2016).

\subsubsection{Nuisance and Harmful Species}

Nuisance and harmful species are a barrier to the shellfish industry. These are animals which negatively impact the cultured species, to the extent they can kill entire stocks within days (Callaway et al., 2012). These species can be native or non-native. Non-native species are those that have been intentionally or unintentionally introduced outside their native range (Callaway et al., 2012; Maggs et al., 2010). If these species become established and threaten biodiversity or cause economic damage, they are known as 'invasive' (Callaway et al., 2012; Wilcove et al., 1998). In the UK and Ireland, the annual cost of invasive species to the aquaculture industry is estimated to be $£ 1.7$ billion a year. Although this is probably an underestimate as there is little distinction between native and non-native species during pest control operations (Williams et al., 2010). The cost associated with invasive species occurs through the fouling of nets, cages, buoys, moorings, boat hulls and the cultured species themselves (Callaway et al., 2012; Williams et al., 2010), competition for resources such as space and food, or, predation and parasitism (Callaway et al., 2012). In particular, the invasive marine microalgal Sargassum multicum has been noted in the literature as a nuisance species to shellfish cultivation in NI. It was first detected in Strangford Lough in 1995 (Kraan, 2008) and possesses characteristics that allow it to outcompete local species including; tolerance to a wide range of salinities and temperatures, a high growth and reproduction rate and a diplontic and monoecious life cycle. It is thought $S$. muticum was unintentionally introduced into Europe via the import of oysters 
into France from Canada or Japan for aquaculture. Thereafter, natural transmission, boating

627

628

629

630

631

632

633

634

635

636

637

638

639

640

641

642

643

644

645

646

647

648

649

650

activities and movements of oysters facilitated its spread throughout Europe (Kraan, 2008).

The likelihood of colonisation rate is dependent on factors such as currents, prevailing winds and geography. But, once established S. muticum competes for hard substrate and space, alters the ecosystem in shallow waters and has been associated with fouling of equipment, boat propellers and oyster beds. Moreover, the species cannot be eradicated and its control involves seasonal harvesting in problem areas which can be repetitive and laborious. Other species which have become established in the UK and Ireland have had an impact on aquaculture industries in other countries through fouling include: Didemnum vexillum (Coutts and Forrest, 2007), Ciona intestinalis (Ramsay et al., 2008), Styela clava (Thompson and MacNair, 2004) and Botrylloides vioaceus (Bock et al., 2011), although similar consequences are yet to be reported in this region.

\subsubsection{Harmful Algal Blooms}

A Harmful Algal Bloom (HAB) is a rapid increase or accumulation of phytoplankton (also known as microalgae) in the water which causes injury to animals or the ecology. It is recognised by a discolouration in the water from their pigments and often only represents a small proportion of the total phytoplankton biomass (Callaway et al., 2012). However, if large enough the algal bloom can cause problems and become a barrier to shellfish cultivation (Hinder et al., 2011). Phytoplankton can become indigestible when they are nutrient starved, probably due to accumulation of noxious secondary metabolites, and act as ecosystem disruptive algal blooms (EDAB's) (Callaway et al., 2012; Mitra and Flynn, 2006). Such phytoplankton block the natural flow of energy and elements through the food chain (e.g. Phaeocystits). Consequently, bivalves are food deprived and, when dying, EDABs cause further damage through decay (e.g. hypoxia). More commonly, HAB's are associated with shellfish poisoning (McCoy et al., 2015; Anderson et al., 2012; Lopez-Rivera et al., 2010; 
651 Hallegraeff, 2003; Smayda, 1990). This is the result of the natural toxin production of algae 652 and the subsequent accumulation in the shellfish through filter feeding. These toxins are associated with a number of serious and potentially fatal human illnesses (EFSA, 2009; FAO, 2004) and include: dinoflagellates such as Alexandrium associated with the production of paralytic shellfish poisoning (PSP); Dinophysis producing lipophilic shellfish toxins (LST) responsible for Diarrheic Shellfish Poisoning (DSP) and Azaspiracid Shellfish Poisoning (AZP); and diatoms such as Pseudonitzschia linked to amnesic shellfish poisoning (ASP) (Bresnan et al., 2010; Lopez-Rivera et al., 2010; Read and Fernandes, 2003). Unlike marine pathogens, these toxins cannot be eliminated through food processing techniques and depuration is inefficient (Jennings et al., 2016). Instead, surveillance testing and maximum permitted levels exist in order to reduce the human health risk. If toxin levels are detected above the maximum permitted levels the site will be closed down (EC, 2004). This poses a substantial barrier to shellfish production. A barrier exacerbated by the fact HAB's are difficult to predict and challenging to avoid. Fortunately, NI harvesting areas have been only slightly impacted by $\mathrm{HAB}$ related events. Although, they are recognised as having increased in distribution, intensity and frequency over the last 40 years (Hallegraef, 2003) with sites in Scottish and Irish waters closed as a consequence (Bresnan et al., 2010). These trends are believed to be due to, in part, increasing temperatures and climate change effects. It is therefore important to become proactive, gaining an understanding of HAB's and preparing the industry should they become prominent in this region. In general $\mathrm{HAB}$ related events occur near the shore. However, they may originate off-shore through seeding and advection. They are primarily associated with sunny, warm and stable water conditions (Callaway et al., 2012) but have also been linked to terrestrial processes following anthropogenic activity including: nutrient inputs; changes to local marine ecosystems affected by land use and human population growth; and changes in 
676 Bresnan et al., 2010). Climate change may also create opportunities for new analogies of toxin 677 groups currently present in UK waters and the introduction of new species of toxin-producing

678 phytoplankton (Turner et al., 2015). Another risk factor for toxins is an imbalance of N:P rations within phytoplankton, which can occur due to the use of P-fertilizer, sewage systems and heavy rainfall (Bresnan et al., 2010; Youlian et al., 1998). Whilst Si stress, which can occur due to limited run-off during reduced rainfall, is linked with toxicity for the diatom Pseudonitzschia australis, a common species off the UK (Youlian et al., 1998). Another recognised contributing factor is ocean acidification (Callaway et al., 2012). This is because alkaline waters are detrimental to algal growth (Hansen, 2002) and as algal blooms consume $\mathrm{CO}_{2}$, nitrate and phosphate (alkalisation of the water), the lower the starting $\mathrm{pH}$, the longer species succession can occur (Callaway et al., 2012).

\subsubsection{Chemical}

Chemical hazards are chemical substances that cause harm or injury to the health of living organisms. They are a barrier to shellfish production as they can accumulate in the flesh of shellfish following uptake in food or water in the cultured area(Jennings et al., 2016). Chemicals in the aquatic environment include: dichlorodiphenyltrichloroethane (DDT); dioxins; endosulfan; heavy metals such as methyl-mercury, cadmium, lead and arsenic; persistent organic pollutants; pesticides; polybrominated di-phenyl ethers; polychlorinated biphenyls (PCBs); and polycyclic aromatic hydrocarbons (PAHS) (Jennings et al., 2016; Soon and Baines, 2012). The variation in chemical concentration is dependent on: the location; shellfish characteristics (i.e. host type, fat content, size, age, growth rate and gender); and other physical, chemical and biological factors (Jennings et al., 2016). Chemicals act as neurotoxins and can have carcinogenic effects, posing a threat to public health. In areas or consumers which consume high quantities of shellfish, chemicals have a bio-accumulative effect. Health risks are associated with chronic (long-term) exposure, whilst vulnerable individuals can be at risk 
from acute short term exposure (Jennings et al., 2016; Grandjean and Landrigan, 2014; Oken et al., 2012; Mahaffey et al., 2011; Nesheim and Yaktine, 2007; Sunderland, 2007; Knowles et al., 2003). However, the nutritional benefits from shellfish are thought to outweigh any potential risks (Crovato et al., 2017; EC, 2001). Regulation EC/1881/2006 defines the maximum levels for contaminants in live bivalve molluscs. In 2011, the European Food Standards Agency (EFSA) set a new, more stringent and combined limit of $30 \mu \mathrm{g} / \mathrm{kg}$ (as opposed to the previous individual limit of $10 \mu \mathrm{g} / \mathrm{kg}$ ) for four key PAHs, known as EFSA4, (Benzo(a)pyrene, Chrysene, Benzo(a)anthracene and Flouranthene) in live bivalve molluscs. In NI, DAERA and Food Standards Agency (FSA) operate a joint monitoring program for a suite of chemicals in shellfish flesh. This determines whether shellfish are harvested or not (DOENI, 2016). Monitoring is carried out annually, usually in February or March, as this represents pre-spawning when the burden of contaminants on the shellfish body is at its highest. Generally, contamination of shellfish by chemical contaminates is low in most production areas. However, since the new limit was set for EFSA4, monitoring in Narrow Water has demonstrated levels of PAHs at or above the EFSA4 therefore continued surveillance is prudent (DOENI, 2016).

\subsubsection{Physical}

Physical hazards are foreign objects in food which can cause choking, injury or other adverse health effects when eating. In NI, shellfish cultivation is typically exported to foreign markets live in the shell. As a result, physical hazards are generally well controlled but can include shell in the flesh and metal or plastic from equipment or environment. Recently, plastic particle contamination, principally micro and nanoparticles of plastic in marine and fresh water systems have raised concerns regarding their impacts on shellfish, human health and potential to aggregate and spread pathogens (IFREMER, 2017; UNEP and DESA, 2013). Plastic is durable, can accumulate in marine habitats (accounting for up to $90 \%$ of all marine debris) (IFREMER, 
2017; UNEP and DESA, 2013), and can break down to smaller fragments and exist as microplastics (MPs) $(<1 \mathrm{~mm})$ or nanoplastics $(\mathrm{NPs})(<1 \mu \mathrm{m})$. At this smaller size, plastic can accumulate and persist in the bivalve mollusc for 48hours (IFREMER, 2017; Browne et al., 2008) where it has been linked with a strong inflammatory response (granulocytomas) and presentation of destabilisation of the lysosomes (IFREMER, 2017; Von Moos et al., 2012). Recent research also shows an affinity of polystyrene particles for contaminants such as flouranthene (Paul-Pont et al., 2016) which could potentially cause accumulative effects.

\subsubsection{Radiation}

Radiation is energy given off by an unstable nucleus. This radiation is in the form of rays or high-speed particles and is a waste product during the normal operations of a nuclear site. The amount of radioactive waste is controlled however, it can contaminate shellfish and enter the food chain when released into the sea acting as a barrier to production (Jennings et al., 2016). In the UK, a number of nuclear sites exist, however none of these are located in NI. Nevertheless, the NI Environment Agency (NIEA) carry out food, environmental and dose rate monitoring to confirm the safety of the food chain from radionuclide pollutants and establish long-term trends. This is necessary due to the continued use and proposed increase of nuclear sites (CEFAS, 2016; Jennings et al., 2016). At present, consumer doses in NI are less than $1 \%$ of the annual limit of $1 \mathrm{mSv}$ for members of the public and thus not of significant concern (Fig. 3) (CEFAS, 2016).

\subsection{Technical}

Technical factors are those which have an impact on how a business operates. They include: Management Decisions; Training and Experience; Research; Collaboration; Availability of Resources; and Storage and Distribution systems.

\subsubsection{Management Decisions}


750

751

752

753

754

755

756

757

758

759

760

761

762

763

764

765

766

767

768

769

770

771

772

773

774

An APB must achieve sustainable rates of production in order to remain operational. This is managed at site level and is contingent on the management practices and ability of the business to counterbalance any risks to the production, e.g. disease (Dabrowski et al., 2013). These management practices are the decisions the APB makes with regards to the species, cultivation method, growing conditions, time of production, harvesting method, handling practices and surveillance and mitigation measures implemented (Jennings et al., 2016; Callaway et al., 2012; Seafish, 1997). Fox et al. (2018) outlines the production methods and supply chain structure in the UK, predominately involving on-bottom mussel culture and trestle oyster culture. All these decisions can facilitate or act as a barrier to production as they affect: the robustness, quality and safety of the bivalve mollusc; productivity and economic viability of the harvesting site; and the ability to meet regulatory requirements (Oidtmann et al., 2011). For example, mussels are a robust species but stress and multiple small impacts can have a cumulative effect, damaging the shell and resulting in death. Thus, it is important to consider handling operation, equipment design and workforce discipline in order to increase productivity (Seafish, 1997). Similarly, a failure to investigate optimum levels of cultivation for a harvesting site can result in increased competition for resources, over-exploitation of an area and decreased productivity and profitability of an APB (Nunes et al., 2011; Ferreira et al., 2008). These management decisions are not isolated to that of the aqua-culturist, but also to other stakeholders in the supply chain. For example, the period and location of sampling carried out by surveillance agencies can impact the likelihood of detecting pathogens and contaminants, especially those with seasonal dynamics. The management decisions made in the supply chain are dependent on a number of other technical factors, including: their training and experience to allow them to make knowledgeable and effective decisions; the mitigation options developed and advocated through data; and research shared with the industry.

\subsubsection{Training and Experience}


775 Aquaculture is a relatively young industry, re-commencing in the 1970's in Ireland. This is a barrier to shellfish cultivation as there is very few second generation farmers passing down their knowledge and experience about the best management options. This is not ideal as shellfish are a very sensitive species which require particular cultivation and handling methods and knowledge of production threats in order to achieve high quality and productive harvest. Moreover, the industry relies on passive surveillance whereby it is the duty of an aqua-culturist to report increased or unusual mortality or suspicion of a notifiable disease. Thus, the sensitivity of the system is vulnerable to a reluctance of reporting due to fear of financial or reputational loss and a lack of understanding of the importance of this responsibility (Oidtmann et al., 2011). Whilst the industry in NI is young, other locations have mastered the production of shellfish species. For example, Bostock et al. (2010) described this as one of the key facilitator's for aquaculture production in Asia as the pre-existing aquaculture practices. Best practices and lessons learnt should be sought and communicated to our aquaculture industry. Moreover, in many locations, most aqua-culturist farmers have attained a university degree in aquaculture. This is not provided or common in NI. Typically aqua-culturist have progressed from working in the wild fisheries and have learnt the trade through a process of trial and error. There is space to increase the productivity of shellfish cultivation in NI by greater knowledge understanding, training and sharing of experiences alone.

\subsubsection{Research}

In the EU, the use of scientific research to investigate the current risks, potential threats and effective solutions is advocated (Nunes et al., 2011). It is critical this research is communicated to the end user in a meaningful matter, providing effective training and optimising management decisions. It has been cited that the lack of conclusive data in aquaculture research, particularly on a region by region basis is a barrier to aquaculture (Read and Fernandes, 2003). For example, the recent emergence of OsHV-1 $\mu$ var and Vibrio aestuarianus questions our ability to predict 
and prevent the spread of potential new emerging pathogens (IFREMER, 2017). In addition, the eradication of Marteilia refringens and Bonamia ostreae is not possible. Thus, a better understanding of the dynamics of these parasites is required to identify their impact on shellfish cultivation and construct relevant stock management, conservation or restoration measures (IFREMER, 2017). Another barrier to the industry is the lack of systems in place to report and share data. For example depuration centres need to comply with requirements related to mollusc disease. However, we currently lack data defining disinfection and water treatment efficiency. Similarly, data regarding mortality and biosecurity measures is missing for mollusc production. Moreover, the current predicative models and mitigation measures utilised in the industry vary in complexity, scale and scope of application with many not sufficient to manage risks (Covato et al., 2017; Nunes et al., 2011; Ferreira et al., 2008). The control system is reactive and the 'just-in-time' approach causes barriers and concern for the profitability of the APB and continuity of supply for consumers (Jennings et al., 2016). Ultimately, a greater effort on aquaculture research, specifically dedicated to key threats and data deficiencies specific to each aquaculture production region, is crucial to sustain and grow shellfish cultivation. Provisions need to be made for more and better research (Read and Fernandes, 2003).

\subsubsection{Collaboration}

Research is key to gain an understanding of bivalve production, the risks and solutions. However, for this research to become effective and provide solutions to the industry it must improve the understanding of the end user. The current level of engagement and dissemination has been described as inadequate and ineffective (Turnball et al., 2011). Stakeholders are an important source of information providing critical perspectives and new insights on production risks and solutions. Thus, the integration of the stakeholder's perspective is vital for defining meaningful research goals. Similarly, discussing the resultant findings with the end user will optimise scientific research results. The end user (e.g. farmers, retailers, government etc.) have 
the best understanding of the farming system and are key to establishing the aspects which can be manipulated to reduce such threats (Turnball et al., 2011). In addition, governance of the aquaculture supply chain involves many stakeholders which carry out individual testing (regulatory and voluntary). At present, these data results are not shared between proprietor and other stakeholders. This information could be used to analyse trends, identify opportunities and establish an Integrated Coastal Zone Management (ICZM) approach which combines the objectives for various resource users within the coastal zone (Read and Fernandes, 2003). A number of collaborative projects have been undertaken to help achieve this goal and illustrate their important role in establishing effective scientific guidelines for aquaculture, e.g. AQUASPACE, ICES, MARAQUA and OAERRE. More collaborative work in this area can only be beneficial.

\subsubsection{Availability of resources}

Resources is the stock or supply of raw materials which are required for an APB to function. For shellfish cultivation an aqua-culturist requires species, facilities and equipment. In NI, species availability has been described as a barrier mussel farmers, whilst French hatcheries provide a consistent supply seed to facilitate the oyster industry (Habrey and Evans, 2016; Jennings et al., 2016). In particular, spat recruitment and growth described as a greater risk than disease to mussel farmers in Scotland (Murray et al., 2012). This problem could increase due to climate change and may require a greater reliance on hatchery produced seed or a more resilient species (Callaway et al., 2012; Cooley and Doney, 2009). Facilities are another crucial resource. Shellfish cultivation requires a suitable location which provides optimum conditions for growth. In NI, shellfish cultivation makes use of suitable and naturally existing coastal habitats (Callaway et al., 2012). However, a shortage of suitable sites; competition for that space from other users which take precedence e.g. tourism; and the ecological carrying capacity of existing sites have been identified as limiting factors to the developments of the kind seen 

carrying capacity of an area is defined as the standing stock at which the annual production of marketable cohort is maximised. It takes account of physical, ecological and social aspects of production (Ferreira et al., 2008). In terms of bivalves, this includes primary production, detrital inputs and exchange with adjacent ecosystems at the ecosystem scale; and, substrate, shelter and food transported by tidal currents and density-dependent food depletion at the local scale (Ferreira et al., 2008). It is vital to determine the carrying capacity of an area to ensure a sufficient supply of food, prevent over-exploitation and to minimise any ecological impacts. There is potential for shellfish cultivation to expand offshore, particularly as cultivation structures develop and other un-used models exist e.g. wind farms, however this has not been explored in NI (Lacoste et al., 2018; Nunes et al., 2011; Kapetsky et al., 2010). Another important resource to cultivate, harvest and protect shellfish is equipment. It is vital the material used to construct equipment does not transfer harmful substances to the molluscs and it is resistant to seawater. However, such specialised equipment and storage containers add expense and may never return from distant destinations. Normal agricultural equipment are relatively inexpensive but, they are generally unsuitable for molluscs as they can be difficult to clean, susceptible to corrosion and have reduced protective abilities. Thus, the reduced cost may be compensated for through unnecessary loses during production, handling, storage and transport (Seafish, 1997).

\subsubsection{Storage and Distribution Systems}

Bivalve molluscs are sensitive animals, prone to temperature stress, physical shocks and contamination. Thus any breakdown or delays during storage or distribution act as a barrier to

872 shellfish production (Crovato et al., 2017; Jennings et al., 2016). This is particularly concerning 873 for shellfish cultivation in NI as it is embedded in a global market involving import of seed and export of live shellfish and relies heavily on the function of supply chains that involve transport 
by air or sea. An example of the uncertainty and risk this can introduce into the supply chain was illustrated in July 2015 when delays in the Channel Tunnel had devastating consequences to the Scottish seafood production and export business as their customers were rejecting or cancelling their orders due to deterioration. In addition, it's recommended that the live product is held in the protected and clean environment of a transport vehicle or a storage room in cool $\left(2-5^{\circ} \mathrm{C}\right.$ with the exception of blue mussels which should be iced) and moist conditions (Seafish, 1997). Throughout this stage, the product must remain packaged and sealed until offered for sale to the retailer, caterer or consumer, although it may be repackaged (and subsequently, relabelled). It is critical that the finished product is protected and remains traceable throughout this process. Moreover, any stresses on the shellfish, e.g. over-heating, physical drop or other damage, has a cumulative effect. Repeated incidents of relatively minor mishandling can result in the death of the animal and reduced economic return to the APB. Should the shellfish be held out of water, their eating quality deteriorates over time to the extent that their flavours become sour and undesirable to the consumer well before any physical response indicates death (Crovato et al., 2017). The smooth running of transport, storage and distribution systems are therefore critical for shellfish quality and safety, and also to the supply chains and consumers it supports (Jennings et al., 2016).

\subsection{Political}

Political factors are those relating to government policies and administrative practices that can have an effect on an APB. They include Legislation or Certification schemes which can prove to be both a barrier and facilitator to production.

\subsubsection{Legislation}

NI is part of the UK and Europe. The region has been a member of the European Union (EU) for 45 years. However, in June 2016 the EU referendum took place and the people of the UK 
voted to leave the EU. The departure date is scheduled for Friday $29^{\text {th }}$ March 2019. The post Brexit regulations and issues around the NI border remain unclear. This brings huge uncertainty

901

902 and potential to an APB in terms of regulations and trade agreements in the near future. At present, the sector is subject to legislation laid out at International, European, National and Regional levels which considers a variety of demands including: environmental pressures, animal welfare, food safety, productivity and innovation (Alexander et al., 2015). At European level, a common policy and legal framework for aquatic health has been developed. The aquaculture sector comes under the remit of the Common Fisheries Policy (CFP). These regulations stipulate that member states (MS) must adopt provisions which comply with the objectives, conservation, monitoring, resource management, environmental and technical controls, and, reporting of aquaculture statistics stated in EU Directives (Read and Fernandes, 2003). Along with the 2013 revision of the CFP (EC, 2013), the Common Aquaculture policy, Blue Growth agenda (EC, 2012) and the strategic guidelines for MS (EC, 2013), the EU Commission intends to recognise and facilitate aquaculture in a sustainable and environmentally sound way (Ferreira et al., 2008). Additionally, the EU is committed to the principles of the precautionary approach, including guidelines for aquaculture in the FAO Code of Conduct for Responsible Fisheries, in which Article 9 covers aquaculture development, and other international initiatives including the ICES Code of Practice on the Introductions and Transfers of Marine Organisms (Ferreira et al., 2008; ICES, 2005). In NI, regional legislation, codes of conduct and codes of practice defines the responsibilities and procedures required to adhere to EU Directives and international agreements, whilst focusing its effort on regional and national needs (Read and Fernandes, 2003). In practice, compliance with these measures requires registration of an $\mathrm{APB}$, adherence to a biosecurity plan and inspection and monitoring. In NI, registration of an APB is authorised by the Department of Agriculture, Environment and Rural Affairs under EU Directive (2006/88/EC) (EC, 2006) and the Aquatic Health Regulations 
924 (NI). The authorisation process is required to ensure the APB has the rights to the resources being cultivated, including the protection of these resources (Oidtmann et al., 2011). It typically has a number of conditions attached, including: species, location, production rates, water and waste discharges, interactions with other users, movement and disease control, drugs and pesticides, feed and food safety, monitoring and record keeping (Alexander et al., 2015; Oidtmann et al., 2011; Read and Fernandes, 2003). In order to attain registration of an APB registration, the APB must secure a licence and gain access to the land and water. A licence is issued under Section 11 of the Fisheries Act (1996) by the Environmental Marine and Fisheries Group (EMFG) within DAERA. There are two types of licence applicable to shellfish cultivation in Northern Ireland (1): Fish culture licences which are compulsory for all fish and shellfish farms. It is an offence to operate without this licence or in breach of any conditions attached, and; (2): Shellfish fishery licences which are optional additional licences for shellfish farmers which gives the licence holder the exclusive right to cultivate a particular species of shellfish within a specified area (and so the exclusive right to take that shellfish from an area) whilst protecting their operations (DAERA, 2018). The EMFG evaluates the proposed shellfish production; carrying capacity and suitability of the site; and potential environmental impacts. They will grant a licence based on the outcome of this assessment. This approval process is necessary to comply with the Water Framework Directive (EC, 2000), Marine Strategy Framework Directive (EC, 2008) and The Water Framework Directive Regulations (NI) 2003 governing water and waste water (Alexander et al., 2015; Dabrowski et al., 2013). Access to land and water is a necessary stage to ensure an APB has access to and occupation of the sea bed and coastal land areas for a long period of time to allow cultivation. It is governed by the EU Habitats Directive and planning regulations. In NI, coastal zones and the seabed (where shellfish cultivation takes place) is classified as state property and are owned by the Crowns Estate, an independent commercial business created by an Act of Parliament to maintain and 
enhance the value of the crown estate. Thus, a Crown Estate Lease is necessary to exercise the planning permission or licence granted for aquaculture developments (DAERA, 2018; Seafish, 2016). An APB must also construct and submit a documented BMP to the Fish Health Inspectorate (FHI) for approval. This plan identifies the veterinarian for the farm, risks from importing disease via shellfish movements, other activities which may spread disease on site, mitigation and monitoring procedures and the accidental introduction of non-indigenous species, coupled with a list of actions to take in such events. Once this BMP has been approved aquaculture operations can commence. Thereafter, a number of governing bodies are responsible for monitoring and inspection to ensure licence conditions and legislation are adhered to. The FHI is part of DAERA and they are responsible for compliance to the EU Directive 2006/88/EC which stipulate requirements for animal health. This legislation makes it an offence to place aquaculture species on the market unless they are clinically healthy and an offence to spread disease (Alexander et al., 2015). Council directives also require health certificates and veterinary checks for animals when moved in and out of the EU. The FHI audit farms at least once a year to ensure compliance to their BMP; take samples for laboratory analysis; and ensure movement and mortality are maintained for three years, health surveillance records are maintained for 5 years (requirement of the veterinary medicines regulations) and information on animal transport retained for a minimum of 2 years (Oidtmann et al., 2011). The Food Safety Authority (FSA) ensures food safety and carries out the monitoring of requirements in The EU Shellfish Growing Water Directives for the health and quality standards of shellfish for human consumption. This legislation stipulates the level of contaminants and algal toxins permitted in shellfish for human consumption (Gingagaspero et classified according to the degree of contamination with faecal indicator bacteria, occurrence of toxins and presence of causative organisms. The legislation gives the FSA extensive powers 
to close or prohibit shellfish harvesting where microbiological standards or biotoxins levels are exceeded (Read and Fernandes, 2003). Additional conditions are placed on APB's which are located in Natura 2000 sites. These include Special Areas of Conservation (SAC) under the

977 Habitats Directive (92/43/EEC) and Special Protection Areas (SPAs) designated under the 978 Birds Directive (79/409/EEC) (O'Carroll et al., 2016). Other stakeholders also exist in the aquaculture supply chain. The Agri-Food and Biosciences (AFBI) are a non-departmental public body who carry out high technology research and development, statutory, analytical and diagnostic testing functions for DAERA on the aquaculture sector. The Loughs agency is an enforcement body for the Lough Foyle, Carlingford and Irish Lights Commission (FCILC) which was established under the Good Friday Agreement to promote the development of the Foyle and Carlingford Loughs for commercial and recreational matters, including aquaculture. The aim of all this legislation and enforcement bodies is to protect the consumer and environment whilst facilitating the maintenance and development of the aquaculture industry. , However, the extent of regulations have been criticised for constraining the industry in Europe and North America. This concern is heightened by the fact legislation and monitoring adapt and grow as a result of the ever increasing debate about the effect aquaculture has on the environment (Alexander et al., 2015; Dabrowski et al., 2013; Hannon et al., 2013; Nunes et al., 2011; Read and Fernandes, 2003). Interestingly, Asia dominates the worldwide aquaculture production. The relaxed regulatory framework, in comparison to that in other regions, e.g. the European Union, has been described as one of the driving factors for the rapid increase in production in this region (Bostock et al., 2010). Conversely, NI retrieves a high economic return for its products and its disease free status allows entry into lucrative markets. The regulatory regime has been deemed as one of the most important factors is achieving the reputation of quality and safe products. This reinforces the important and pivotal role 
regulations and political factors can play in production output and value. It is important to get the balance right.

\subsubsection{Certification Schemes / Self-Regulation}

Self-regulation is the act of regulating oneself without intervention from external bodies. Institutional measures which are linked to legislative requirements, such as codes of conduct or codes of best practice, have been recognised as useful mechanisms of self-regulation at international, national and aquaculture producer association levels. Typically, codes of conduct (e.g. the FAO of the UN adopted a Code of Conduct for Responsible Fisheries in 1997 which includes aquaculture development) comprise of a set of general rules and principles that should lead to the responsible and sustained development of the industry, whilst codes of best practice provide guidelines for aquaculture to avoid causing pollution and optimise the environmental management of operations. Both take account of the best available methods, techniques, strains, feeding regimes, environmental sustainability and welfare of animals and other issues relating to aquaculture (Read and Fernandes, 2003). These measures, if used responsibly by Producer Associations, can facilitate the shellfish industry through voluntary restraints which lead to significant quality control and allow competitive advantage. Moreover, they instil sectoral responsibility and allow members to demonstrate their attitudes towards the environment and the consumer. Typically a code of conduct is accompanied by proactive actions within the sector, such as certification schemes (Read and Fernandes, 2003). Certification schemes define, inform and assure buyers and consumers on a particular certified attribute of a product. It goes beyond the requirements within legislation. They typically use a logo on product packaging or advertisement to illustrate the certified attribute which represents provenance, environmental sustainability and/or human or animal welfare standards. For 
example, a Chain of Custody Standard aims to ensure traceability and segregation of products throughout the supply chain. These attributes are increasingly important considerations for producers, buyers and sellers in societies where people want to make choices about how they produce and source food (Jennings et al., 2016; Ward and Phillips, 2008). Certified products tend to be more expensive, but the certified attributes matter enough to add value or reduce risk for producers or buyers who can afford to make a choice (Jennings et al., 2016). Different schemes have different standards and there is ongoing debate about appropriate benchmarks for sustainability and the relationship between selected benchmarks and societal expectations (Jennings et al., 2016). In aquaculture, a large proportion of production is certified. Consequently, some certification schemes have become a necessary customer requirement placing extensive working standards and a financial burden on the APB to remain in the marketplace. Although, no single player has yet achieved the same dominance as the MSC in wild-capture sector (Jennings et al., 2016).

\subsection{Welfare}

Welfare in aquatic food production falls under three key aspects: Animal, People and Environment. In NI, APB's must adhere to the legal standards for welfare and the ethical expectations of society (Jennings et al., 2016). However, concerns have been raised about the welfare of people involved in aquatic food production and supply; environmental sustainability of production systems; the use of genetically modified species and; animal welfare. These concerns are becoming increasingly highlighted by lobby groups and certification bodies who raise awareness and influence the choices made by a proportion of customers and consumers (Jennings et al., 2016).

\subsubsection{Animal}


Aquaculture operations affects the quality of life and health of animals and the industry must act in accordance to the Animal Welfare Act of 2006 (UK Government, 2006). Stocking density, diet, and management procedures all affect welfare prior to death. In shellfish cultivation, the more stress the species encounters the lower the quality of flesh. As a result, bivalves are typically treated and handled with upmost care and animal welfare is actually an advantage of shellfish production.

\subsubsection{People}

The welfare of people working in the fisheries, aquaculture and food processing sectors has received considerable media attention (Jennings et al., 2016). Internationally, reports on the aquatic supply chain have involved thousands of people relating to bonded, forced and child labour and other modern day slavery and health and safety violations (Jennings et al., 2016; International Labour Organisation, 2013). In this supply chain a large proportion of production relies on industries where workers can be and/or are exposed to a higher risk of injury, death and human right abuses than many other jobs (Fox et al., 2018; Jennings et al., 2016). Some of these supply chains are known to support UK consumption. For example, in Morecambe Bay in February 2004, 23 of 38 illegal immigrants from China died when they were cut off by a rising tide whilst collecting cockles (Cerastoderma edule, Cardiidae). The gang master showed no consideration for the health and safety of its workers and was sentenced to 14 years in prison for manslaughter (in practice he was deported back to China in 2012). This event prompted the Modern Slavery Act of 2015 which consolidated existing human trafficking and slavery offences. However, there are still continued reports of human welfare issues in the aquatic supply chain. These are primarily associated with the wild fisheries (SOCA, 2013). Whilst aquaculture does not have a similarly high offence rate, it does involve relatively high fatalities. For example, the Scottish aquaculture industry endured 5 fatal accidents from 2003-2013 (Health and Safety Executive, 2014), equating to a rate of approximately 25 per 100,000year 
${ }^{1}$. Therefore, it is necessary to ensure aquaculture production continues to generate food whilst supporting the communities and providing socially acceptable working conditions for the people involved (Jennings et al., 2016).

\subsubsection{Environment}

Aquaculture production causes a range of concerns from aesthetic to pollution issues affecting the current and future state of the environment (Jennings et al., 2016; Nunes et al., 2011; Smith et al., 2011). In particular, shellfish cultivation typically requires large areas of space in coastal areas. The presence of structures can reduce the natural beauty of the area, cause conflicting demands for coastal resources with other users; changed habitat and hydrodynamics at the site; and public concern around the visual aesthetics of structures in coastal areas (McKindsey et al., 2011; Ferreira et al., 2008; Read and Fernandes, 2003). Similarly the aquaculture operations, e.g. the use of destructive gear for seed collection, heavy vehicles accessing cultivation areas and release of chemicals from machinery, can alter, destruct or contaminate the natural habitats (O'Carroll et al., 2016; Forde et al., 2015). In addition, shellfish cultivation has been negatively associated with the consumption of phytoplankton, which reduces the availability of food for wild populations (Ferreira et al., 2008), and results in the bio-disposition of faecal material (Forde et al., 2015). This material enriches the sediment below with organic material and increases the oxygen demand of the area. Observations generally follow the model of organic enrichment and oxygen deficiency (Darbowski et al., 2013; Pearson and Rosenber, 1978). Consequently, species tolerant to high organic loading replace stress sensitive individuals and the diversity in benthic communities is reduced (Nunes et al., 2011). Studies have reported varying levels of impact. Some report significant reductions in bottom oxygen concentrations, increases of tolerant species and the formation of extensive bacterial mats under cultivation structures. Whilst, others have reported no or minimal significant effect in the community structure (Nunes et al., 2011). The level of impact has been related to distance from 
the aquaculture structures (greatest effects seen in areas closet to cultivation structures); site location (impact is lower in offshore sites); the hydrographic conditions (areas with high tidal currents prevent the accumulation of organic material); and the size and frequency of production (greater production rates have greater effects) (Lacoste et al., 2018; Forde et al., 2015; Read and Fernandes, 2003). One potential mitigation measure to address aquaculture byproducts is Integrated Multi-Trophic Aquaculture (IMTA). This method involves using the byproducts including waste from one aquatic species as inputs for another. However, this practice has not been used for shellfish cultivation in NI. A report by Seafish (2016) outlines the need for a rigorous economic feasibility assessment and subsequent funding opportunities before the exploration of innovative projects such as IMTA in this region. Other ecosystem consequences include the dumping of mortalities, introduction of non-indigenous species which may escape to become invasive and displace wild populations or, cause genetic interactions with the wild (Nunes et al., 2011); introduction and increased intensity and frequency of pathogens and disease and their transfer from the farmed to wild species and; an increased frequency of harmful algal blooms (Nunes et al., 2011; Read and Fernandes, 2008). Each of these environmental effects have the potential to change the predator and competitor composition (Tidbury et al., 2016; Parker and Tyedmers, 2014; Werschkun et al., 2014). Shellfish cultivation also has positive effects to biodiversity and it is important to consider these whilst assessing environmental welfare. The cultured species can help preserve biodiversity as it reduces predation pressure on commonly harvested wild species; increases the local and total productivity of an area if site selection is good (related to flushing and dispersal of nutrients); provides biodiversity recovery by reducing pressure on commonly harvested species; helps increase light penetration in the water column; and; improves the ecological status of the area, i.e. shellfish are filter feeders and can extract nutrients and contaminants from the water column, and; provides the market with high quality farmed shellfish (Nunes et al., 2011; 
Ferreira et al., 2008). Moreover, for any remaining environmental consequences or concerns, an environmental impact assessment is carried out and reviewed by DAERA and its associated bodies to prevent long term ecological effects. This is part of the licencing system in NI. In general, bivalve cultivation has a relatively small impact in comparison to semi-intensive and intensive aquaculture systems; production involves high productivity in a small area and; impacts tend to be localised around production sites (Jennings et al., 2016; Hall et al., 2011).

\subsection{Market}

The market is the customers who pay a sum of money to purchase and/or consume shellfish, returning profits to the APB. Their needs and wants play a crucial role in the supply, demand and success of aquaculture production (Callaway et al., 2012).

In terms of needs, NI is part of the UK, a relatively wealthy nation claiming the fifth highest GDP in the world (IMF, 2015). Consequently, many other sources of nutrition are available and the supply of aquaculture is often focused on meeting the wants and expectations of consumers. These demands typically include food quality, quantity, safety, welfare, nutrition and price (Jennings et al., 2016). Health is a key motivation for aquatic food consumption. However, it is relatively expensive and many people tend to eat what they can afford as opposed to food they prefer. This encourages consumers to 'trade down' or eat less, reducing the amount they buy. Other barriers to consumption include a lack of knowledge about how to prepare shellfish, lack of available fresh shellfish locally, preparation time, dislike of the smell and need for meal planning (Jennings et al., 2016). There is also fear a disease outbreak, health scares or campaign groups may lead to a consumer boycott and threaten the export market (Jennings et al., 2016; Alexander et al., 2015). Health concerns are a particular concern since these commonly arise from contamination during handling, processing or storage by distributors, retailers and the consumer and thus pose an uncontrollable risk to the reputation 
and safety of an APB and the shellfish industry (Croato et al., 2017). Similarly, campaign or lobbying groups may intensify pressure by increasing consumer awareness and perceived impact of environmental and public health issues related to shellfish. For example, such groups can confuse and scare consumers through focusing heavily on the potential presence of microorganisms, bio-toxins and chemicals in shellfish rather than considering the likelihood and benefits of consuming aquatic food. Therefore, risk communication in the supply chain is a very important element which should be addressed, particularly as risky behaviours by consumers including inappropriate storage conditions from storage to home, lack of respect for the cold chain and unsafe handling behaviours during food preparation have been identified as major causes for food disease outbreaks (Crovato et al., 2017). At present, consumer demand in NI is described as quite conservative, with the exception of a few species such as warm water prawns. As a result, cultivated shellfish are predominantly exported as the local market is insufficient and not commanding a high price in comparison to the buoyant export markets (Habrey and Evans, 2016). This is contrary to the report from WHO (2010) who stated international trades in bivalves is very much regionalised with many regions unable to penetrate distant markets outside their province mainly due to technical barriers such as strict regulations on imports of bivalve products. This is a distinct advantage for NI shellfish production which is able to access major markets due to their strong reputation for high regulatory standards and disease free status (DAERA, 2018). The growing population, income growth and urbanisation will continue to create market opportunities (Kharas, 2010). However, this may also prompt the global growth of the industry and create competition from regions where current production is low but lower production costs and regulation and ignorance to environmental consequences of non-sustainable production allow aquaculture to be offered at a much lower price (Jennings et al., 2016; Nunes et al., 2011). Nevertheless, in parallel to the trend for intensification in areas (such as Asia) there is a growing demand for improved high quality, nutritious safer to eat 
shellfish products occurring within the region (FAO, 2017b). This provides vital opportunities to NI and puts it in a unique position with its disease free and strict environmental welfare

1171 attributes attractive to these markets. The balance between global growth of aquaculture; trends

1172 in demand for aquatic food, outside and inside the UK; and the value placed on NI shellfish 1173 will likely influence the likelihood of investment in expanding aquaculture production in NI 1174 (Jennings et al., 2016). In order to access these markets and gain a strong market position, it is 1175 vital NI develops marketing structures and strategies. This importance is evident from the fact 1176 the industry in Africa and parts of Latin America suffered due to the lack of well-developed 1177 markets and an ability to reach them (Bostock et al., 2010). It is also important to consider the 1178 impact of changing climatic conditions which may become unfavourable for current species and potentially create opportunities for other species. However, it is more likely mitigation 1180 measures to overcome such barriers, rather than substituting the species will occur due to the consumer demand in the local and export market (Callaway et al., 2012). 

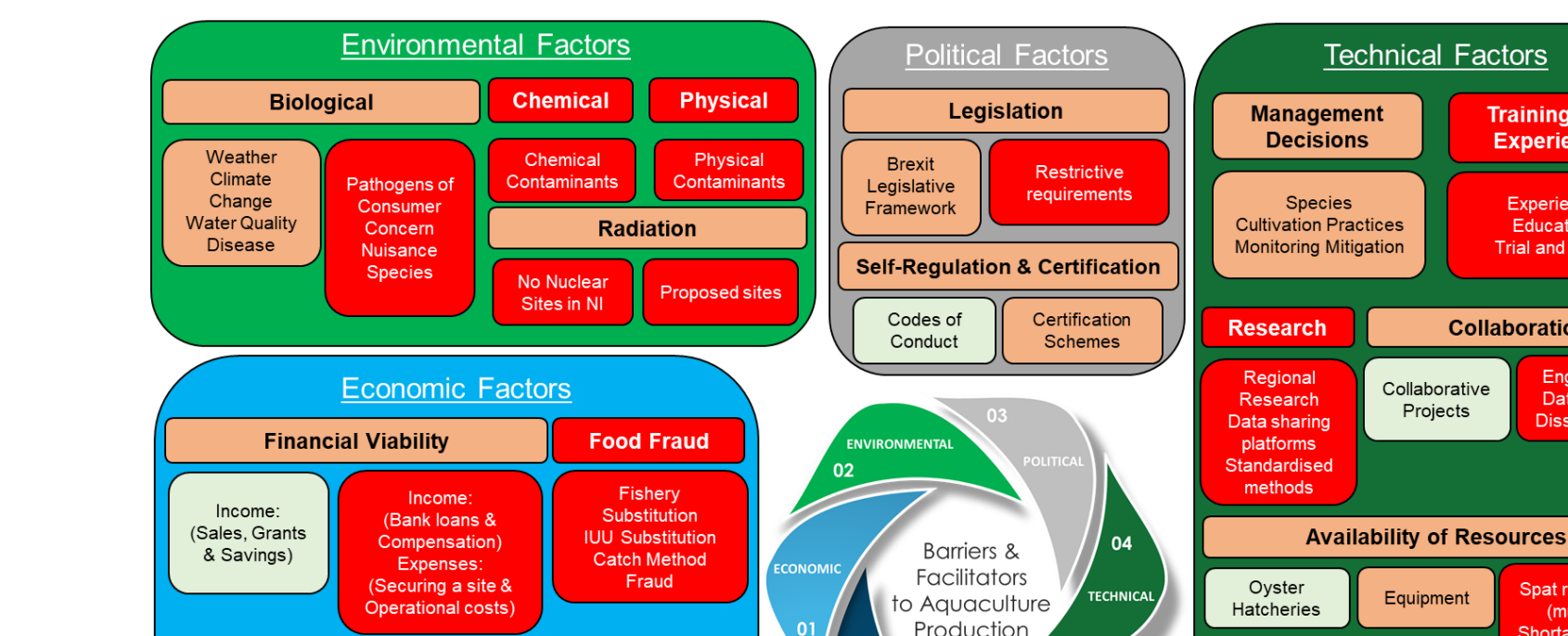

State of the Economy
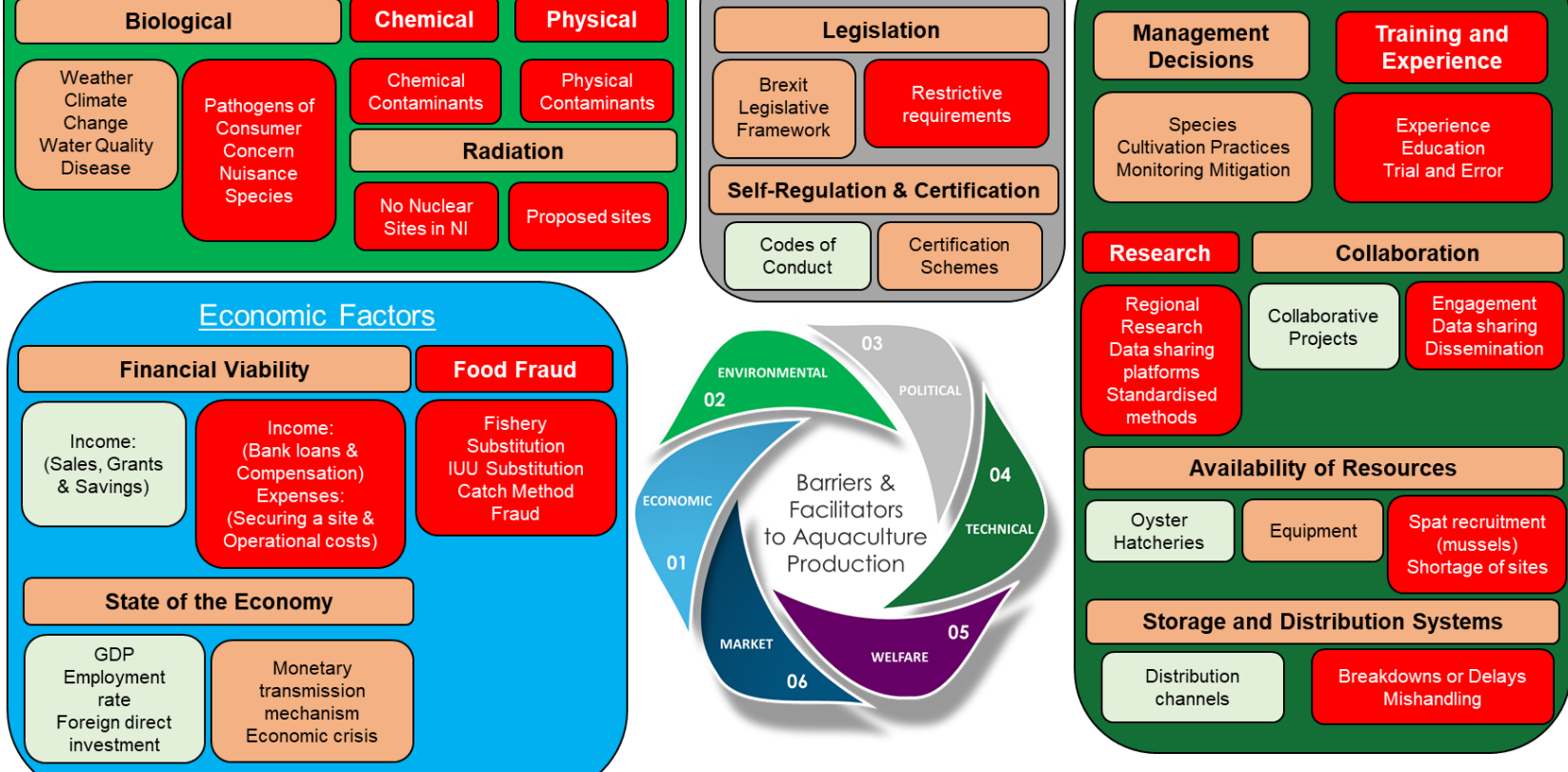

platforms

Standardised

methods
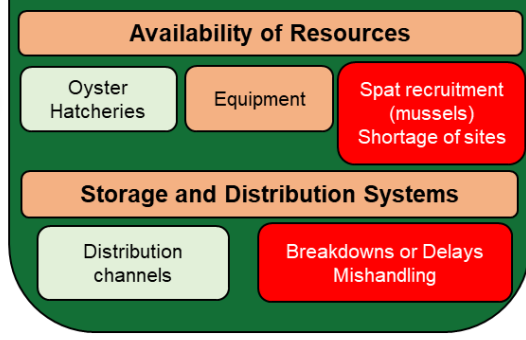

investment
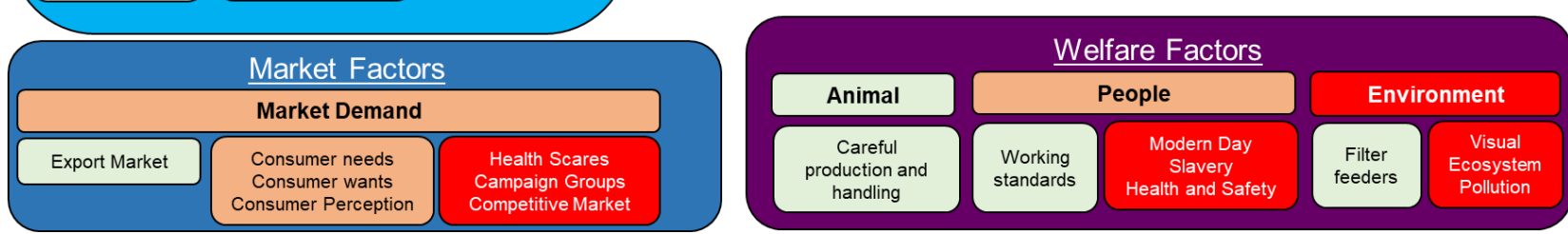

1184 Figure 3: Simplified diagrammatic traffic light illustration of the key barriers and

1185 facilitators to shellfish cultivation in Northern Ireland.

Aquaculture is affected by six key categories: Economic, Environmental, Technical, Welfare, Political and

Consumer factors. Within these categories a number of factors have been identified and illustrated as a facilitator,

barrier or both to shellfish cultivation within Northern Ireland.

\section{Facilitating Growth of Shellfish Production in NI}

1191 The information gained from this review has exposed the current barriers to shellfish 1192 production. These factors are an important advancement to those revealed in global reviews 1193 published by Muir and Young (1998) and Bostock et al., (2010). As recommended by these 1194 authors, it is important to study individual aquaculture industries in relation to these factors. In

$1195 \mathrm{NI}$, it is evident that the availability of suitable sites is a limiting factor. However, there is 
opportunity to increase the productivity of our current production sites. Moreover, the higher requirements in terms of food safety, sustainability, and welfare has contributed to the high value placed on NI shellfish products. This paper argues that this is the key opportunity to increase the profitability of the sector for this region. To allow this increased productivity and profitability the following recommendations have been determined based on the results discussed throughout the review:

1. Carry out a comprehensive review of the current financial support available to the industry and establish suitable funding mechanisms for growth (e.g. Capital Investment Schemes, Aquaculture Loan Arrangements, Aquaculture Subsidies and Insurance Options; Departmental budget for continued surveillance; and Research Grants to relevant research and development projects).

2. Translate scientific research into meaningful policy, procedural best practices and an economically viable model that will achieve sustainable production; improved farm profitability and resiliency; and more efficient use of resources.

3. Establish a platform to report and share data and create a robust scientific base of key statistics, economic trends and production data for the aquaculture industry.

4. Facilitate stakeholder engagement and partnerships between all members of the aquaculture supply chain, other water users, academia, government and consumers to address current challenges in our system, establish key opportunities for growth and deliver a shared strategy which makes a significant contribution to our aquaculture sector, the economy and the environment.

5. Take a consumer centric approach to understand the consumer and establish a Northern Ireland brand based on key unique selling points (e.g. origin green, sustainability, organic, voluntary labelling and certification schemes of consumer interest). 
6. Create timely, feasible and evidence informed policy briefings following a major review of existing regulation and international best practice; research translation; and stakeholder engagement.

7. Assess on-farm training needs and develop a holistic plan for skills development and knowledge transfer to improve production volume and value

8. Carry out a complete assessment of the current marketing structures and promotional activities associated with shellfish cultivation in NI against other successful countries to: create a clear food promotion strategy; proactively promote our NI produce; negotiate market entry; grow sales and exports; pursue new opportunities and improve competitiveness.

9. Encourage innovation along the aquaculture supply chain, inspire entrepreneurs and work in partnership with other bodies (e.g. engineering firms, R\&D services and business) for the commercialisation of robust, easy to use, rapid and inexpensive automatic equipment, mitigation measures, analytical techniques and value added products.

10. Speak as a truly co-ordinated representable body which lobbies and supports for the aquaculture industry; bridges the gap between each of the stakeholders in the shellfish supply chain; advocates changing course on shellfish legislation; develops the skills and entrepreneurship of the industry; takes a leading role in improving the quality of coastal waters and takes responsibility for innovation funding to ensure a consistent and shared approach across industry.

A number of key stakeholders already exist in the NI aquaculture sector (see political factors). A potential structure to ensure a collaborative and effective effort to undertake these recommendations could involve the amalgamation of suitable personnel from each of these organisations into a working group or professional body. The responsibility for each action or 
recommendation is then delegated among those personnel (and organisations). This structure 1245 is outlined in Fig. 4.

1246 In conclusion, the opportunities which exist for aquaculture production are extensive and 1247 lucrative, particularly due to a growing population and plateauing wild fisheries Shellfish 1248 cultivation is impacted by a complex set of economic, environmental, technical, welfare, 1249 political and market factors. Each of these factors interact differently dependent on the 1250 aquaculture producing country. In order to engage in a strategic partnership to optimise global 1251 aquaculture production it is important for each region to define the role each factor plays in 1252 their industry. In NI, the priority is to ensure increased productivity of the current licenced sites coupled with high standards of production across the region. This will allow niche marketing opportunities of premium shellfish products into major and profitable markets. In NI a greater appreciation and effort to address data deficiencies coupled with the provision of financial, 1256 procedural and legislative support is required. This will: stimulate investment; improve 1257 competitiveness and productivity; and allow the industry to maximise its potential contribution to our local economy. The creation of a working group or professional body may provide a suitable structure to facilitate this and assign responsibility and accountability for each of the recommendations defined. 


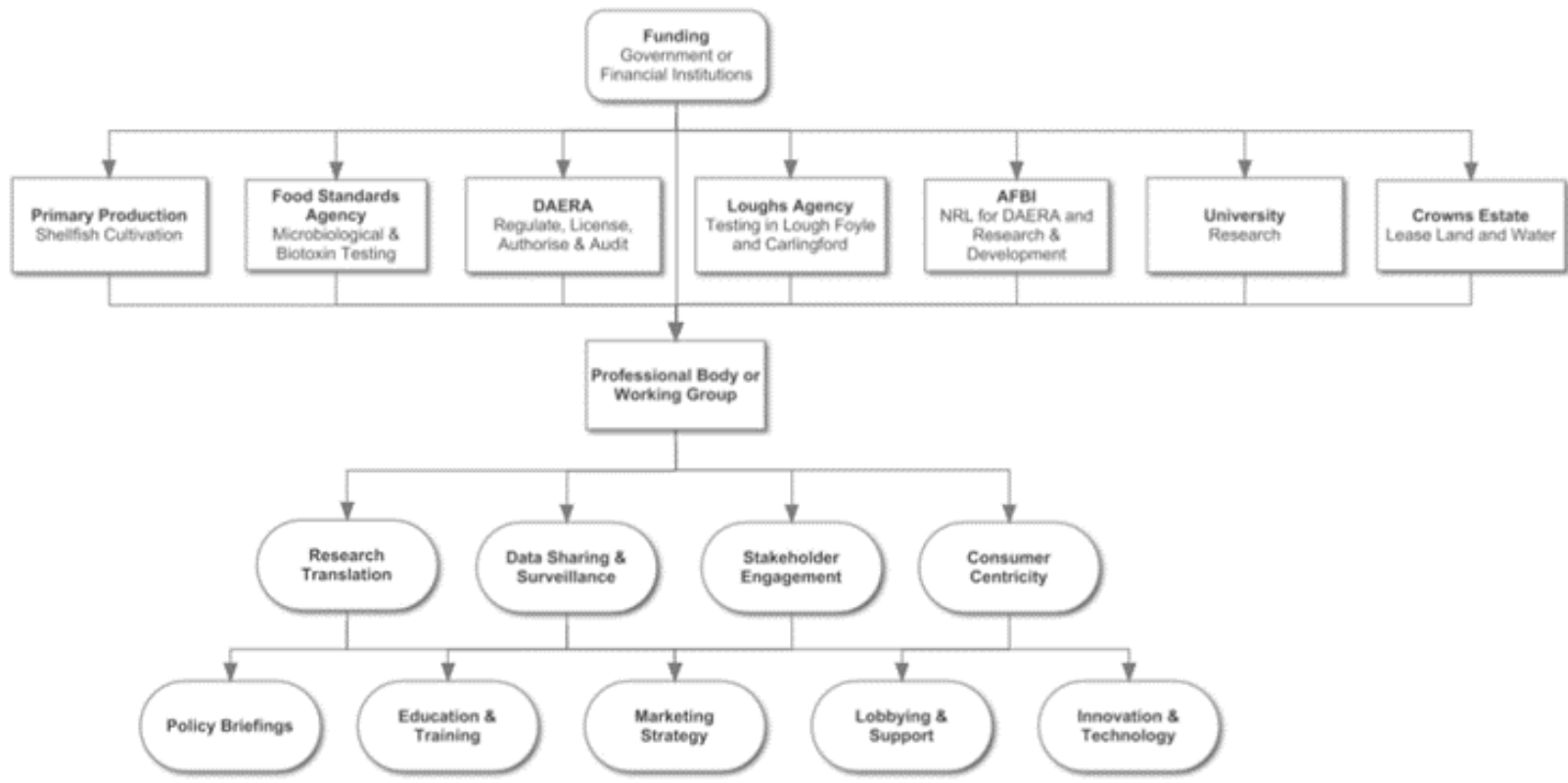

In order to facilitate a sustainable and profitable aquaculture sector government funding is needed to continue surveillance and research and development projects. The funding should be allocated following a comprehensive review of the financial status of the sector. The ongoing work within the sector and the recommendations within this review should be allocated to the appropriate stakeholders. The creation of a working group would facilitate co-operations between academia, industry, government and consumers to identify and address barriers in the aquaculture supply chain; identify research gaps; provide a platform for data sharing and surveillance; translate research to enable the development of new culture practices, technologies and solutions for farmers and decision makers; provide education and training for effective knowledge exchange; advocate and lobby to update shellfish legislation; and deliver a clear customer centric marketing strategy.

\section{Acknowledgements}

1274 The authors would like to acknowledge the financial support provided by the Department of Agricultural, Environment and Rural Affairs (DAERA) for funding of the PhD Aquaculture Security. The authors of this paper are linked to the Institute for Global Food Security, Queens

1277 University, Belfast and Agri-Food and Biosciences Institute, Northern Ireland. 
Alexander, K.A., Potts, T.P., Freeman, S., Israel, D., Johansen, J., Kletou, D., Meland, M., Pecorino, D., Rebours, C., Shorten, M. and Angel, D.L. 2015. The implications of aquaculture policy and regulation for the development of integrated multi-trophic aquaculture in Europe. Aquaculture, 443, pp. 16-23.

Altekruse, S.F., Bishop, R.D. and Baldy, L.M. (2000). Vibrio gastroenteritis in the US Gulf of Mexico region: the role of raw oysters. Epidemiology and Infection, 124, pp. 489-495.

Anderson, D.M., Alpermann, T.J., Cembella, A.D., Collos, Y., Masseret, E. and Montresor, M. (2012). The globally distributed genus Alexandrium: multifaceted roles in marine ecosystems and impacts on human health. Harmful Algae, 14, pp. 10-35

Arzul, I., Corbeil, S., Morga, B. and Renault, T. (2017). Viruses infecting marine molluscs. Journal of Invertebrate Pathology, 147, pp. 118-135.

Azrul, I., Langlade, A., Chollet, B., Robert, M., Ferrand, S., Omnes, E., Lerond, S., Couraleau, Y., Joly, J.P., François, C. and Garcia, C. (2011). Can the protozoan parasite Bonamia ostreae infect larvae of flat oysters Ostrea edulis? Veterinary Parasitology, 179, pp. 6976.

Baker-Austin, C., McArthur, J.V., Lindell, A.H., Wright, M.S., Tuckfield, R.C. and Gooch, J. (2009). Multi-site analysis reveals widespread antibiotic resistance in the marine pathogen Vibrio vulnificus. FEMS Microbiology Ecology, 57, pp. 151-159.

Baker-Austin, C., Stockley, L., Rangdale, R. and Marti-Nez-Urtaza, J. (2010). Environmental occurrence and clinical impact of Vibrio vulnificus and Vibrio para-haemolyticus: a European perspective. Environmental Microbiology Reports, 2, pp. 7-18

Baker-Austin, C., Trinanes, J.A., Taylor, N.G.H., Hartnell,R., Siitonen, A. and MartinezUrtaza, J. (2013). Emerging Vibrio risk at high latitudes in response to ocean warming. Nature Climate Change, 3, pp. 73-77. 
Barange, M., Merino, G., Blanchard, J.L. et al. (2014). Impacts of climate change on marine ecosystem production in societies dependent on fisheries. Nature Climate Change, 4, pp. 211-216.

BBC News. (2016). Oyster farms cashing in on politics dispute. [online] Available at: https://www.bbc.co.uk/news/uk-northern-ireland-38256155 [Accessed 30 May 2018].

BIM. (2008). Progress Report. [online] Dublin: Aquaculture Initiative, pp.1-19. Available at: http://www.aquacultureinitiative.eu/Aqua_Report_1.pdf [Accessed 22 May 2018].

Bock, D.G., Zhan, A., Lejeusne, C., MacIsaac, H.J. and Cristescu M.E. (2011). Looking at both sides of the invasion: patterns of colonization in the violet tunicate Botrylloides violaceus. Molecular Ecology, 20, pp. 503-516.

Bostock, J., McAndrew, B., Richards, R., Jauncey, K., Telfer, T., Lorenzen, K., Little, D., Ross, L., Handisyde, N., Gatward, I. and Corner, R. (2010). Aquaculture: global status and trends. Philosophical transactions of the Royal Society of Biology, 365, pp. 2897-2912.

Brander, K.M. (2007). Global fish production and climate change. Proceedings of the National Academy of Sciences of the United States of America, 104(50), pp. 19709-19714.

Bresnan, E., Fernand, L., Davidson, K., Edwards, M., Milligan, S., Gowan, R., Sike, J., Kröger, S. and Raine, R. (2010). Climate change impacts on harmful algal blooms (HABs.) In: MCCIP Annual Report Card 2010-11, MCCIP Science Review. Available at: www.mccip.org.uk/arc [29 May 2018].

Bridges, V.E., Akkina, J., Grannis, J., Johnson, C., Johnson,R. and Tuszynski, C. (2007). A qualitative assessment tool for the potential of infectious disease emergence and spread. Preventive Veterinary Medicine, 81, PP. 80-91.

Brown, J.H., McLeod, D.A. and Scott, D.C.B. (2006). Development of best practice in relation to movement of bivalve shellfish stock. Report of Project No FC1017/CSA7049, commissioned by DEFRA, pp. 68. 
Browne, R., Deegan, B., Watson, L., Mac Giolla Bhríde, D., Norman, M., O’Cinnéide, M., Jackson, D., O’Carroll, T. (2008). The status of Irish aquaculture 2007. Ireland: Reports Compiled by MERC Consultants, pp. 144

Burgiel, S.W. and Muir, A.A. (2010). Invasive species, climate change and ecosystem-based adaptation: Addressing multiple drivers of global change. Washington, DC, US and Nairobi, Kenya: Global Invasive Species Programme (GISP): 56.

Burrows, M.T., Schoeman, D.S., Buckley, L.B. et al. (2011). The pace of shifting climate in marine and terrestrial ecosystems. Science, 334, pp. 652-655.

Byers, J.E., Reichard, S., Randall, J.M., Parker, I.M., Smith, C.S., Lonsdale, W.M., Atkinson, I.A., Seastedt, T.R., Williamson, M., Chornesky, E. and Hayes D. (2002). Directing research to reduce the impacts of nonindigenous species. Conservation Biology, 16, pp. $630-640$.

Callaway, R., Shinn, A.P., Grenfell, S.E., Bron, J.E., Burnell, G., Cook, E.J., Crumlish, M., et al., (2012). Review of climate change impacts on marine aquaculture in the UK and Ireland. Aquatic Conservation: Marine and Freshwater Ecosystems, 22(3), pp. 389421.

Carnegie, R.B., Arzul, I. and Bushek, D. (2016). Managing marine mollusc diseases in the context of regional and international commerce: policy issues and emerging concerns. Philosophical Transactions Royal Society Publishing, 371, pp. 1-11.

CEFAS. (2016). Radioactivity in Food and the Environment, 2015, RIFE-21. [online]. London: Centre for Environment, Fisheries and Aquaculture Science. Available at: https://www.sepa.org.uk/media/219578/rife-21.pdf [Accessed 30 May 2018].

Cheung, W.W.L., Lam, V.W.Y., Sarmiento, J.L., Kearney, K., Watson, R., Zeller, D. and Pauly, D. (2010). Large-scale redistribution of maximum fisheries catch potential in the global ocean under climate change. Global Change Biology, 16, pp. 24-35. 
Clegg, T.A., Morrissey, T., Geoghegan, F., Martin, S.W., Lysons, K., Ashe, S. and More, S.J. (2014). Risk factors associated with increased mortality of farmed Pacific oysters in Ireland in 2011. Preventative Veterinary Medicine, 113, pp. 257-267.

Cochrane, K., De Young, C., Soto, D. and Bahri, T. (2009). Climate change implications for fisheries and aquaculture: overview of current scientific knowledge. FAO Fisheries and Aquaculture Technical Paper, No. 530. Rome: Food and Agricultural Organisation of the United Nations.

Coen, L.D., Brumbaugh, R.D., Bushek, D., Grizzle, R., Luckenbach, M.W., Posey, M.H., et al. (2007). Ecosystem services related to oyster restoration. Marine Ecology Fundamental and Applied, 341, pp. 303-307.

Cooley, S.R. and Doney, S.C. (2009). Anticipating ocean acidification's economic consequences for commercial fisheries. Environmental Research Letters, 4, pp. 1-8.

Corlett, R.T. (2012). Climate change in the tropics: The end of the world as we know it? Biological Conversation, 151, pp. 22-25.

Coutts, A.D.M. and Forrest, B.M. (2007). Development and application of tools for incursion response: Lessons learned from the management of the fouling pest Didemnum vexillum. Journal of Experimental Marine Biology and Ecology, 342, pp. 154-162

Crovato, S., Pinto, A., Arcangeli, G., Mascarello, G. and Ravarotto, L. (2017). Risky behaviours from the production to consumption of bivalve molluscs: Involving stakeholders in the prioritization process based on consensus methods. Food Control, 78, pp. 426-435.

Dabrowski, T., Lyons, K., Cure, M., Berry, A. and Nolan, G. (2013). Numerical modelling of spatio-temporal variability of growth of Mytilus edulis (L.) and influence of its cultivation on ecosystem functioning. Journal of Sea Research, 76, pp.5-21.

Dabrowski, T., William, J.D., Lyons, D.K. and Nolan, G.D. (2014). Numerical modelling of 
blue mussel (Mytilus edulis) bacterial contamination. Journal of Sea Research, 89, 5263.

DAERA, 2013. Declaration from the United Kingdom for disease-free status for Ostreid herpesvirus (OsHV-1 $\mu$ Var) under Article 43 of Council Directive 2006/88/EC, Version 2. [online]. Belfast: DAERA, pp. 1-24. Available at: https://www.daerani.gov.uk/sites/default/files/publications/dard/declaration-from-the-united-kingdomfor-disease-free-status-for-ostreid-herpesvirus.pdf [Accessed 12 May 2018].

DAERA. (2018). Introduction to aquaculture | Department of Agriculture, Environment and Rural Affairs. [online] Available at: https://www.daera-ni.gov.uk/articles/introductionaquaculture [Accessed 18 May 2018].

Degremont, L., Guyader, T. and Pepin, J.F. (2013). Is horizontal transmission of the Ostreid herpesvirus OsHV-1 in Crassostrea gigas affected by unselected or selected survival status in adult juveniles. Aquaculture, 408, pp. 51-57.

De Silva, S.S. (2012). Climate change impacts: challenges for aquaculture. In: Subasinghe, R.P., Arthur, J.R., Bartley, D.M., De Silva, S.S., et al. (eds), Farming the waters for people and food. Proceedings of the Global Conference on Aquaculture 2010. FAO, Rome: FAO and Bankok, pp. 75-110.

De Silva, S.S. and Soto, D. (2009). Climate change and aquaculture: potential impacts, adaptation and mitigation. In: Cochrane, K., De Young, C., Soto, D., Bahri, T. (eds), Climate change implications for fisheries and aquaculture: overview of current scientific knowledge. FAO Fisheries and Aquaculture Technical Paper, No. 530. FAO: Rome, pp. 151-212.

Dechet, A.M., Yu, P.A., Koram, N. and Painter, J. (2008). Non-foodborne Vibrio infections: an important cause of morbidity and mortality in the United States, 1997-2006. Clinical Infectious Diseases, 46, pp. 970-976. 
DEFRA (2014). Bonamiosis. London: Department of Environment, Food and Rural Affairs, pp.1-2. Available at: https://assets.publishing.service.gov.uk/government/uploads/system/uploads/attachme nt_data/file/292127/Guide_to_bonamiosis.pdf [Accessed 18 May 2018].

Degremont, L., Ernande, B., Bedier, E. and Boudry, P. (2007). Summer mortality of hatchery produced Pacific oyster spat (Crassostrea gigas). An estimation of genetic parameters for survival and growth. Aquaculture, 262, pp. 41-53.

Degremont, L., Boudry, B., Ropert, M., Samain, J.F., Bedier, E. and Soletchnik, P. (2010). Effects of age and environment on survival of summer mortality by two selected groups of Pacific oyster Crassostrea gigas. Aquaculture, 299, pp. 44-50.

DOENI (2016). 2015 Review of Shellfish Water Protected Areas. Belfast: Department of the Environment, $\quad$ pp. 1-27. Available at: $\underline{\text { https://www.daera- }}$ ni.gov.uk/sites/default/files/consultations/doe/marine-consultation-2015-reviewshellfish-water-protected-areas-2016.pdf [Accessed 14 May 2018].

Doubleday, Z., Clarke, S., Li, X., Pecl, G., Ward, T., Battaglene, S., Frusher, S., Gibbs, P., Hobday, A., Hutchinson, N., Jennings, S. and Stoklosa, R. (2013). Assessing the risk of climate change to aquaculture: a case study from south-east Australia. Aquaculture Environment Interactions, 3, pp. 163-175.

Dube, C., Ribble, C., Kelton, D. and McNab, B. (2011). Introduction to network analysis and its implications for animal disease modelling. Revue Scientifique et Technique, 30, pp. 425-4436.

Dunne, S., Hanafin, J., Lynch, P., McGrath, R., Nishimura, E., Nolan, P., Ratnam, J.V., et al. (2009). Ireland in a warmer world - Scientific predictions of the Irish climate in the twenty-first century. Ireland: Environmental Protection Agency. ISBN: 978-1-84095307-7 
EC. (2000). Council Directive 2000/60/EC of the European Parliament and of the Council of 23 October 2000 establishing a framework for Community action in the field of water policy. Official Journal of the European Union, L327, pp.1.

EC. (2001). Opinion of the Scientific Committee on Food on the risk assessment of dioxins and dioxin-like PCBs in food (update based on the new scientific information available since the adoption of SCF opinion of 22 November 2000). European Commission, Brussels. Available at: http://europa.eu.int/comm/food/fs/sc/scf/outcome_en.html [Accessed 30 Nov. 2018].

EC. (2004). Corrigendum to regulation (EC) No 584/2004 of the European Parliament and of the council 29 April laying down specific riles for the organisation of official controls on products of animal origin intended for human consumption. Official Journal of the European Union, L226, PP. 83-127.

EC. (2006). Council Directive 2006/88/EC of 24 October2006 on animal health requirements for aquaculture animals and products thereof, and on the prevention and control of certain diseases in aquatic animals. Official Journal of the European Union L328, pp. 14-56.

EC. (2008) Directive 2008/56/EC of the European Parliament and of the Council. Establishing a framework for community action in the field of marine environmental policy (Marine Strategy Framework Directive). Official Journal of the European Communities, L164, pp. 19-40.

EC. (2012). Commission Staff Working Document on the Implementation of National Residue Monitoring Plans in the Member States in 2012 (Council Directive 96/23/EC). European Commission, Brussels.

EC. (2013). Regulation (EU) No 1380/2013 of the European Parliament and of the Council of 
11 December 2013 on the Common Fisheries Policy, amending Council Regulations (EC) No 1954/2003 and EC No 1224/2009 and repealing Council Regulation (EC) No 2371/2002 and (EC) No 639/2004 and Council Decision 2004/585/EC. Official Journal of the European Union, 354, 22-61.

EFSA. (2009). Scientific opinion of the panel on contaminants in the food chain - saxi-toxin group. EFSA Journal, 1019, pp. 1-76.

EFSA. (2010). Scientific opinion on the increased mortality events in Pacific oysters, Crassostrea gigas. EFSA Journal, 8, pp. 1894.

EFSA. (2015). Statement on the benefits of fish/seafood consumption compared to the risks of methylmercury in fish/seafood. European Food Safety Authority Journal, 13, pp. 1982.

EFSA and ECDC. (2015). The European summary report on trends and sources of zoonoses, zoonotic agents and food-borne outbreaks in 2014. EFSA Journal, 13(2), pp. 191.

Elliott, C. (2014). Elliott Review into the Integrity and Assurance of Food Supply Networks Final Report. A National Food Crime Prevention Framework. London: HM Government, pp.1-145.

European Commission. (2016). JCR Scientific and Policy Reports: Economic Report of EU aquaculture Sector (STECF-16-19). Brussels: Reports of the Scientific, Technical and Economic Committee for Fisheries (STECF), pp.1-485.

FAO. (2004). Marine Biotoxins. FAO Food and Nutrition Paper, 80, pp. 278.

FAO. (2010). World aquaculture 2010. [online] Rome: Food and Agriculture Organisation of the United Nations, pp. 1-120. Available at: http://www.fao.org/docrep/014/ba0132e/ba0132e.pdf [Accessed 4 Dec 2018].

FAO. (2016). The state offood and agriculture: Climate change, agriculture and food security. [online] Rome: Food and Agriculture Organisation of the United Nations, pp. 1-194. Available at: http://www.fao.org/3/a-i6030e.pdf [Accessed 3 May. 2018]. 
FAO. (2017a). FishStatJ. FAO, Rome. Available at: http://www.fao.org/fishery/statistics/software/fishstatj/en [Accessed May 2018].

FAO. (2017b). Regional review on status and tends in aquaculture development in Asia-Pacific - 2015, by Rohana Subsainghe. FAO Fisheries and Aquaculture Circular No. 1135/5. Rome, Italy.

Ferreira, J.G., Hawkins, A.J.S., Monteiro, P., Moore, H., Service, M., Pascoe, P.L., Ramos, L. and Sequeira, A. (2008). Integrated assessment of ecosystem-scale carrying capacity in shellfish growing areas. Aquaculture, 275, pp. 138-151.

Flannery, J., Rajko-Nenow, P., Winterbourn, J.B., Malham, S.K. and Jones, D.L. (2014). Effectiveness of cooking to reduce Norovirus and infectious F-specific RNA bacteriophage concentrations in Mytilus edulis. Journal of Applied Microbiology, 117, pp. 564-571.

Focardi, S., Corsi, I. and Franchi, E. (2005). Safety issues and sustainable development of European aquaculture: new tools for environmentally sound aquaculture. Aquaculture International, 13(1-2), pp.3-17.

Forde, J., O’Beirn, F.X., O’Carroll, J.P.J., Patterson, A. and Kennedy, R. (2015). Impact of intertidal oyster trestle cultivation on the Ecological Status of benthic habitats. Marine Pollution Bulletin, 95, pp. 223-233.

FSA. (2018). List of Northern Ireland classified shellfish beds and their associated harvesting areas. [online]. Northern Ireland: Food Standards Agency. Available at: https://www.food.gov.uk/sites/default/files/media/document/2018-shellfishclassifications-ni.pdf [Accessed 5 Dec 2018].

Fox, M., Mitchell, M., Dean, M., Elliott, C. and Campbell, K. (2018). The seafood supply chain from a fraudulent perspective. Food Security, 4(10), pp. 939-963.

Garcia, C., Thebault, A., Degremont, L., Arzul, I., Miossec, L., Robery, M., Chollet, B., 
Francois, C., Joly, J.P., Ferrand, S., Kerdudou, N., Renault, T. (2011). Ostreid herpesvirus 1 detection and relationship with Crassistrea gigas spat mortality in France between 1998 and 2006. Veterinary Records, 42, pp. 73.

Ginagaspero, A., Cirillo, R., Lacascella, V., Lonigro, A., Marangi, M., Cavallo, P., Berrilli, F., Cave, D.D. and Brandonisio, O. (2009). Giardia and Cryptosporidium in inflowing water and harvested shellfish in a lagoon in Southern Italy. Parasitology International, 58 , pp. 12-17.

Glibert, P., Icarus Allen, J., Artioli, Y., Beusen, A., Bouwman, L., Harle, J., Holmes, R. and Holt, J. (2014). Vulnerability of coastal ecosystems to changes in harmful algal bloom distribution in response to climate change: projections based on model analysis. Global Change Biology, 20(12), pp.3845-3858.

Gov.uk (2014). Review of the European Fisheries Fund (EFF) in the UK 2014. [online].

Westminster:

UK

Government.

Available

at: https://assets.publishing.service.gov.uk/government/uploads/system/uploads/attachme nt_data/file/481265/Review_of_the_European_Fisheries_Fund_in_the_UK_2014.pdf [Accessed 10 Dec 2018].

Grandjean, P. and Landrigan, P.L. (2014). Neuro-behavioural effects of developmental toxicity. The Lancet Neurology, 13, pp. 330-338

Grodzki, M., Schaeffer, J. and Piquet, J.C. (2014). Bioaccumulation efficiency, tissue distribution, and environmental occurrence of hepatitis E virus in bivalve shellfish from France. Journal of Applied and Environmental Microbiology, 80, pp. 4269-4276.

Habrey, J. and Evans, S. (2016). SR694 Aquaculture in England, Wales and Northern Ireland: An Analysis of the Economic Contribution and Value of the Major Sub-sectors and the Most Important Farmed Species. [online] Strathpeffer: Seafish, pp.1-162. Available at: 
__Sept_2016.pdf [Accessed 25 May 2018].

Hall, S.J., Delaporte, A., Phillips, M.J., Beveridge, M. and O’Keefe, M. (2011). Blue Frontiers: Managing the Environmental Costs of Aquaculture. The World Fish Center, Penang.

Hallegraeff, G.M. (2003). Harmful algal blooms: a global overview. In: Hallegraef, G.M., Anderson, D.M. and Cem-bella, A.D. (eds), Manual on Harmful Marine Microalgae. Paris: UNESCO, pp. 25-49.

Halpern, B.S., Walbridge, S., Selkoe, K.A., Kappel, C.V., Micheli, F., D’Agrosa, C., Bruno, J.F. et al. (2008). A global map of human impact on marine ecosystems. Science, 319, pp. $948-952$.

Handisyde, N.T., Ross, L.G., Badjeck, M.C. and Allison, E.H. (2006). The effects of climate change on world aquaculture: a global perspective. Final Technical Report, Institute of Aquaculture, Stirling UK and the Department for International Development, UK.

Hannon, C., Officer, R.A. and Dorven, J.L. (2013). Review of the technical challenges facing aquaculture of the European abalone Haliotis tuberculate in Ireland. Aquaculture International, 21, pp. 243-254.

Hansen, P.J. (2002). Effect of high pH on the growth and survival of marine phytoplankton: implications for species succession. Aquatic Microbial Ecology, 28, pp. 279-288.

Health and Safety Executive. (2014). Health and Safety in Agriculture in Great Britain, 2014. Health and Safety Executive, London.

Heylar, S.J., Lloyd, H.A.D., de Bruyn, M., Leake, J., Ben-nett, N. and Carvalho, G.R. (2014). Fish product mislabelling: failings of traceability in the production chain and implications for Illegal, Unreported and Unregulated (IUU) fishing. PLoS ONE, 9, pp. 98691

Hinder, S.L., Hays, G.C., Brooks, C.J., Davies, A.P., Edwards, M., Walne, A.W. and Gravenor, 
M.B. (2011). Toxic marine microalgae and shellfish poisoning in the British Isles: history, review of epidemiology, and future implications. Environmental Health, 10, pp. 54

Hobday, A.J., Poloczanska, E.S. and Matear, R. (2008). Implications of climate change for Australian fisheries and aquaculture: a preliminary assessment. Canberra: Report to the Department of Climate Change.

Howarth, R.W. (2008). Coastal nitrogen pollution: A review of sources and trends globally and regionally. Harmful Algae, 8, pp. 14-20.

Huvet, A., Normand, J., Fleury, E., Quillien, V., Fabioux, C., Boudry, P. (2010). Reproductive effort of Pacific oysters: a trait associated with susceptibility to summer mortality. Aquaculture, 304, pp. 95-99.

ICES, (2005). Code of practice for the introductions and transfers of marine organisms 2005. Copenhagen: International Council for the Exploration of the Sea (ICES), pp. 30.

IFREMER. (2017). Annual meeting and technical workshop of the National Reference Laboratories for Mollusc Diseases. Marine Institute, Oranmore.

IMF. (2015). World Economic Outlook, April 2015. International Monetary Fund, Washington, DC, 210 pp. 210.

International Labour Organisation. (2013). Caught at Sea: Forced Labour and Trafficking in Fisheries. International Labour Organisation, Geneva

Jacquet, J.L. and Pauly, D. (2008). Trade secrets: renaming and mislabeling of seafood. Marine Policy, 32, pp. 309-318.

Jennings, S., Stentiford, G.D., Leocadio, A.M., Jeffery, K.R., Metcalfe, J.D. and Katisadaki, I. et al. (2016). Aquatic food security: insights into challenges and solutions from an analysis of interactions between fisheries, aquaculture, food safety, human health, fish and human welfare, economy and environment. Fish and Fisheries, 1, pp. 1-46. 
Johnson, R. (2014). Food fraud and "Economically motivated adulteration of food and food ingredients. [online] United States: Congressional Research Service, pp. 1-45. Available at: https://www.fas.org/sgp/crs/misc/R43358.pdf [Accessed 5 Dec. 2018].

Kaiser, M. and Stead, S.M.M (2002). Uncertainties and values in European aquaculture: communication, management and policy issues in times of "changing public perceptions". Aquaculture International, 10, pp. 469-490.

Kapetsky, J.M., Aguilar-Manjarrez, J., Jenness, J., Ferreira, J.G., (2010). Spatial analysis for the sustainable development of off-the-coast and offshore aquaculture from a global perspective. In: Lovatelli, A., Aguilar-Manjarrez, J., Soto, D. and Hishamunda, N. (Eds.), Offshore mariculture. FAO Fisheries and Aquaculture Technical Paper. No. 549. Rome: FAO.

Karvonen, A., Rintamaaki, P., Jokela, J. et al. (2010). Increasing water temperature and disease risks in aquatic systems: climate change increases the risk of some, but not all, diseases. International Journal for Parasitology, 40, pp. 1483-1488.

Kay, D. (2008). Results of field investigations into the impact of intermittent sewage discharges on the microbiological quality of wild mussels (Mytilus edulis) in a tidal estuary. Water Research, 42, pp. 3033-3046

Keeling, M. and Eames, K. (2005). Networks and epidemic models. Journal of the Royal Society, 2, pp. 295-307.

Kharas, H. (2010). The emerging middle class in developing countries. OECD Development Centre Working Paper, No. 285, pp. 61.

Kleih, U., Linton, J., Marr, A., Mactaggart, M., Naziri, D. and Orchard, J.E. (2013). Marine Policy, 37, pp. 106-114.

Knowles, T.G., Farrington, D. and Kestin, S.C. (2003). Mercury in UK imported fish and 
shellfish and UK-farmed fish and their products. Food Additives and Contaminants, 20, pp. $813-818$.

Kraan, S. (2008). Sargassum muticum (Yendo) Fensholt in Ireland: An invasive species on the move. Journal of Applied Phycology, 20, pp. 825-832.

Lacoste, E., Drouin, A., Weise, A.M., Archambault, P. and McKindsey, C.W. (2018). Low benthic impact of an offshore mussel farm in Îles-de-la-Madeleine, eastern Canada. Aquaculture environment interactions, 10, pp. 473-485.

Le Guyader, F.S., Krol, J., Ambert-Balay, K., Ruvoen-Clouet, N., Desaubliaux, B., Paraudeau, S., Le Saux, J.C., Ponge, A., Pothier, P., Atmar, R.L. and Le Pendu, J. (2010). Comprehensive analysis of a norovirus-associated gastreonteritus outbreak from the environment to the consumer. Journal of Clinical Microbiology, 48, pp. 915-920.

Lees, D. (2000). Viruses and bivalve shellfish. International Journal of Food Microbiology, 59, pp. 81-116.

Lindgren, E., Andersson, Y., Suk, J.E., Sudre, B. and Semenza, J.C. (2012) Monitoring EU emerging infectious disease risk due to climate change. Science, 336, pp. 418-419.

Lopez-Rivera, A., O’Callaghan, K., Moriatry, M., O’Driscoll, D., Hamilton, B., Lehane, M., James, K.J. and Furey, A. (2010). First evidence of Azaspiracids (AZAs): A family of lipophilic polyether marine toxins in scallops (Argopecten purpuratus) and mussels (Mytilus chilensis) collected in two regions of Chile. Toxicon, 55, pp. 692-701.

Lowther, J.A., Gustar, N.E., Powell, A.L., Hartnell, R.E.and Lees, D.N. (2012). Two-year systematic study to assess norovirus contamination in oysters from commercial harvesting areas in the United Kingdom. Applied and Environmental Microbiology, 78, pp. 58125817

Lynch, S.A., Abollo, E., Ramilo, A., Cao, A., Culloty, S.C. and Villalba, A. (2010). 
Observations raise the question if the Pacific oyster, Crassostrea gigas, can act as either a carrier or a reservoir for Bonamia ostreae or Bonamia exitiosa. Parasitology, 137, pp. $1515-1526$.

Maggs, C., Mineur, F., Bishop, J. and T, M. (2010). Non-natives. MCCIP Annual Report Card 2010-2011. Lowestoft: Marine Climate Change Impacts Partnership (MCCIP), pp.112.

Mahaffey, K.R., Sunderland, E.M., Chan, H.M. Choi, A.L., Grandjean, P., Mariën, K., Oken, E., et al. (2011). Balancing benefits of n-3 polyunsaturated fatty acids and the risks of methylmercury exposure from fish consumption. Nutrition Reviews, 69, pp. 493-508.

Malham, S.K., Cotter, E., O'Keeffe, S., Lynch, S., Culloty, S.C., King, J.W., Latchford, J.W. and Beaumont, A.R. (2009). Summer mortality of the Pacific oyster, Crassostrea gigas, in the Irish Sea: the influence of temperature and nutrients on health and survival. Aquaculture, 287, pp. 128-138.

Marquis, N.D., Record, N.R. and Fernández-Robeldo, J.A. (2015). Survey for protozoan parasites in Eastern oysters (Crassostrea virginica) from the Gulf of Maine using PCRbased assays. Parasitology International, 64, pp. 299-302.

Martinez-Urtaza, J., Bowers, J.C., Trinanes, J. and DePaola, A. (2010). Climate anomalies and the increasing risk of Vibrio parahaemolyticus and Vibrio vulnificusillnesses. Food Research International, 43, pp. 1780-1790.

McCoy, G.R., Touzet, N. and Fleming, G.T.A. (2015). Evolution of the MIDTAL microarray: the adaption and testing of oligonucleotide $18 \mathrm{~S}$ and $28 \mathrm{~S}$ rDNA probes and evaluation of subsequent microarray generations with Pyrmnesium spp. cultures and field samples. Environment Science and Pollution Research, 22, pp. 9704-9716.

McCreary, C., Martelli, F., Grierson, S., Ostanello, F., Nevel, A. and Banks, M. (2008). 
Excretion of hepatitis $\mathrm{E}$ virus by pigs of different ages and its presence in slurry stores in the United Kingdom. Veterinary Records, 163, pp. 261-265.

McKindsey, C.W., Archambault, P., Callier, M.D. and Olivier, F. (2011). Influence of suspended and off-bottom mussel culture on the sea bottom and benthic habitats: a review. Canadian Journal of Zoology, 89, pp. 622-646.

Mitra, A. and Flynn, K.J. (2006). Promotion of harmful algal blooms by zooplankton predatory activity. Biology Letters, 2, pp. 194-197.

Muir, J. (2005). Managing to harvest? Perspectives on the potential of aquaculture. Philosophical Transactions of the Royal Society of Biology, 360, pp. 191-218.

Muir, J.F. and Young, J.A. (1998). Aquaculture and marine fisheries: will capture fisheries remain competitive? Journal of Northwest Atlantic Fishery Science, 23, pp. 157-174.

Murchie, L.W., Cruz-Romero, M., Kerry, J.P., Linton, M., Patterson, M.F., Smiddy, M., et al. (2015). High pressure processing of shellfish: A review of microbiological and other quality aspects. Innovative Food Science \& Emerging Technologies, 6(3), pp. 257-270.

Murray, A.G., Marcos-Lopez, M., Collet, B. and Munro, L. (2012). A review of the risk posed to Scottish mollusc aquaculture from Bonamia, Marteilia and oyster herpesvirus. Aquaculture, 370-371(11), pp. 7-13.

Nesheim, M.C. and Yaktine, A.L. (2007). Seafood Choices: Balancing Benefits and Risks. National Academies Press, Washington.

Nunes, J.P., Ferreira, J.G., Bricker, S.B., O’Loan, B., Dabrowski, T., Dallaghan, B., Hawkins, A., O'Connor, B. and O'Carroll, T. (2011). Towards an ecosystem approach to aquaculture assessment of sustainable shellfish cultivation at different scales of space, time and complexity. Aquaculture, 315, pp. 369-383.

O’Carroll, J.P.J., Quinn, C., Forde, J., Patterson, A., O’Brien, F.X. and Kennedy, R. (2016). 
Impact of prolonged storm activity on the Ecological Status of intertidal benthic habitats within oyster (Crassostrea gigas) trestle cultivation sites. Marine Pollution Bulletin, 110, pp. 460-469.

Oidtmann, B.C., Thrush, M.A., Denham, K.L., Peeler, E.J. (2011). International and national biosecurity strategies in aquatic animal health. Aquaculture, 1-2(19), pp. 22-33.

OIE. 2017. Infection with Martellia Refringens, United Kindgom. [online]. France: OIE, pp. 12. Available at: http://www.oie.int/wahis_2/public/wahid.php/Reviewreport/Review?reportid=23805 [Accessed 30 May 2018].

OIE. 2018. Aquatic Animal Health Code (2018). [online]. France: OIE. Available at: http://www.oie.int/index.php?id=171\&L=0\&htmfile=chapitre_xenohaliotis_californie nsis.htm [Accessed 12 May 2018].

Oken, E., Choi, A.L., Karagas, M.R. et al. (2012). Which fish should I eat? Challenges to developing clear, unified fish consumption advice. Environmental Health Perspectives, 120, pp. $790-798$

Parker, R.W. and Tyedmers, P.H. (2014). Fuel consumption of global fishing fleets: current understanding and knowledge gaps. Fish and Fisheries, 16, pp. 684-696.

Paul-Pont, I., Lacroix, C., Fernández, C.G., Hégaret, H., Lambert, C., Le Goïc, N., Frère, L., et al. (2016). Exposure of marine mussels Mytilus spp. to polystyrene micro-plastics: toxicity and influence on flouranthene bioaccumulation. Environmental Pollution, 216, pp. 1-14.

Pearson, T.H. and Rosenberg, R. (1978). Macrobenthic succession in relation to organic enrichment and pollution of the marine environment. Oceanography Marine Biology Annual Reviews, 16, pp. 229-311.

Peeler, E.J., Reese, R.A., Cheslett, D.L., Geoghegan, F., Power, A. and Thrush, M.A. (2012). 
Investigation of mortality in Pacific oysters associated with ostreid herpesvirus-1 $\mu$ var in the Republic of Ireland in 2009. Preventative Veterinary Medicine, 105, pp. $136-143$.

Peeler, E.J., Reese, R.A., Thrush, M.A. (2010). Report on Investigation of Oyster Herpes Virus Infection and Oyster Mortality in the Republic of Ireland in 2009 - A questionnaire Survey. Centre for Environment, Fisheries and Aquaculture Science (Cefas), Weymonth, UK.

Pepin, J.F., Riou, A. and Renault, T. (2008). Rapid and sensitive detection of ostreid herpesvirus 1 in oyster samples by real-time PCR. Virology Methods, 149, pp. 269-276.

Pernet, F., Barret, J., Le Gall, P., Corporeau, C., Dégremont, L., Lagarde, F., Pepin, J.F. and Keck, N. (2012). Mass mortalities of Pacific oysters Crassostrea gigas reflect infectious diseases and vary with farming practices in the Mediterranean Thau lagoon, France. Aquaculture and. Environmental. Interactions, 2, pp. 215-237.

Pocknell, I., Tanner, A. and Ambrose, J. (2017). Port Health. In: S. Battersby, ed., Clay's handbook of environmental health, 21st ed. Milton Park, Abingdon, Oxon: Routledge, p.974.

Potasman, I., Paz, A. and Odeh, M. (2002). Infectious outbreaks associated with bivalve shellfish consumption: a worldwide perspective. Clinical Infectious Diseases, 35, pp. 921-928.

Ramsay, A., Davidson, J., Landry, T. and Arsenault, G. (2008). Process of invasiveness among exotic tunicates in Prince Edward Island, Canada. Biological Invasions, 10, pp. 13111316.

Read, P. and Fernandes, T.F. (2003). Management of environmental impacts of marine aquaculture in Europe. Aquaculture, 226(1-4), pp. 139-163

Renault, T. (2011). Viruses infecting marine molluscs. In: Studies in Viral Ecology (Vol 2):; $1^{\text {st }}$ 
Robelo, J.A.F. and Figueras, A. (1995). The effects of culture-site, depth, season and stock source on the prevalence of Marteilia refringens in cultured mussels (Mytilus galloprovincialis LMK) from Galicia, Spain. Journal of Parasitology, 81, pp. 354-363.

SafeFood. (2014). Climate Change Ireland: The potential impacts of climate change of food safety from an Island of Ireland Prospective. Cork: SafeFood, pp.1-127.

Samain, J.F. (2011). Review and perspectives of physiological mechanisms underlying genetically based resistance of the Pacific oyster Crassostrea gigas to summer mortality. Aquacultire Living Resources, 24, pp. 227-236.

Samain, J.F. and McCombie, H. (2010). Summer mortality of Pacific oyster Crassostrea giga: The Morest Project. $2^{\text {nd }}$ ed. Versailles: Éditions Quae.

Sauvage, C., Pepin, J.F., Lapègue, S., Boudry, P. and Renault, T. (2009). Ostreid herpes virus 1 infection in families of the Pacific oyster, Crassostrea gigas, during a summer mortality outbreak: differences in viral DNA detection and quantification using realtime PCR. Virus Resources, 142, pp. 181-187.

Schikorski, D., Renault, T., Saulnier, D., Faury, N., Moreau, P. and Pepin, J.F. (2011). Experimental infection of Pacific oyster Crassostrea gigas spat by ostreid herpesvirus 1: demonstration of oyster spat susceptibility. Veterinary Resources, 42, pp. 27.

Seafish. (1997). Guidelines for the Harvesting, Handling and Distribution of Live Bivalve Molluscs. [online]. London: The Seafish Industry Authority, pp. 1-132. Available at: http://www.seafish.org/media/Publications/guideline_bivalve_molluscs_facilities.pdf [Accessed 9 May 2018].

Seafish. (2016). The Seafish guide to who's who in UK Aquaculture QII 2016. [online]. 
Seafish,

pp.

$1-10$.

Available

at: LC_AUGUST_2016_2.pdf [Accessed 9 May 2018].

1748

Segarra, A., Pepin, F.J., Arzul, I., Morga, B., Faury, N. and Renault, T. (2010). Detection and description of a particular ostreid herpesvirus 1 genotype associated with massive mortality outbreaks of Pacific oysters Crassostrea gigas, in France in 2008. Virus Resources, 153, pp. 92-99.

Simard F., Ojeda, J. and Haroun, R. (2008). The sustainable development of Mediterranean aquaculture: problems and perspectives. Options Méditérr, 62, pp. 113-124.

Smayda, T.J. (1990). Novel and nuisance phytoplankton blooms in the sea. In: Graneli, E., Sundstrom, B., Edler, L. and Anderson, D.M. (Eds.), Evidence for a global epidemic, In Toxic marine phytoplankton. New York: Elsevier, pp. 29-40.

Smith, A.D.M., Brown, C.J., Bulman, C.M., Fulton, E.A., Johnson, P., Kaplan, I.C., LozanoMontes, H.L. et al., (2011). Impacts of fishing low-trophic level species on marine ecosystems. Science, 333, pp. 1147-1150.

SOCA. (2013). UK Human Trafficking Centre: A Strategic Assessment on the Nature and Scale of Human Trafficking in 2012. Human Trafficking Centre, Serious and Organised Crime Agency, London

Soon, J.M. and Baines, R.N. (2012). Aquaculture farm food safety and diseases risk assessment (AquaFRAM): Development of a spreadsheet tool for salmon farms. Aquaculture Engineering, 49, pp. 35-45.

Stachowicz, J.J., Terwin, J.R., Whitlatch, R.B. and Osman, R.W. (2002). Linking climate change and biological invasions: Ocean warming facilitates nonindigenous species invasions. Proceedings of the National Academy of Sciences of the United States of America, 99: pp. 15497-15500. 
STECF. (2013). The Economic Performance of the EU Aqua-culture Sector (STECF 13-29). Publications Office of the European Union, Luxembourg.

Suffredini, E., Lanni, L., Arcangeli, G., Pepe, T., Mazzette, R., Ciccaglioni, G., et al. (2014). Qualitative and quantitative assessment of viral contamination in bivalve molluscs harvested in Italy. International Journal of Food Microbiology, 184, pp. 21-26.

Sunderland, E.M. (2007). Mercury exposure from domes-tic and imported estuarine and marine fish and shell-fish in U.S. seafood markets. Environmental Health Perspectives. 115, pp. 235-242.

Tewabe, D. (2015). Climate Change Challenges on Fisheries and Aquaculture. International Journal of Aquaculture and Fishery Sciences, 1, pp.006-011.

Thompson, R. and MacNair, N. (2004). An overview of the clubbed tunicate (Styela clava) in Prince Edward Island. Aquaculture and Forestry Technical Report 234. PEI Department of Agriculture and Fisheries, Montague.

Tidbury, H.J., Taylor, N.G.H., Copp, G.H., Garcnacho, E., Stebbing, P.D. (2016). Predicting and mapping the risk of introduction of marine and non-indigenous species into Great Britain and Ireland. Biological Invasions, 18(11), pp. 3277-3292.

Turnball, J.F., Berrill, I.K., Green, D.M., Kaye, R., Morris, D., Murray, A.G., del-Pozo, J. and Shinn, A. (2011). Applied epidemiology with examples from UK aquaculture. Aquaculture Research, 42, pp. 21-27.

Turner, A.D., Powell, A., Schofield, A., Lees, D.N. and Baker-Austin, C. (2015). Detection of the puffer fish toxin Tetrodotoxin in European bivalves, England, 2013 to 2014. Eurosurveillance, 20, pp. 21009.

UK Government (2006). Animal Welfare Act 2006. Chapter 45. The Stationary Office Limited, London.

UNEP and DESA. (2013). Identifying Emerging Issues from the Perspective of the Small Island 
Developing States. [online] Cambridge: Expert Group Meeting co-hosted by the United Nations Environmental (UNEP) and the United Nations Department of Economic and Social Affairs (DESA), pp.1-43. Available at:

https://sustainabledevelopment.un.org/content/documents/1880sidsegm2.pdf

[Accessed 3 Dec. 2017].

United Nations (2015). Resolution adopted by the General Assembly on 25 September 2015. Transforming our world: the 2030 Agenda for Sustainable Development. United Nations, New York,.

United Nations. (2017). World Population Prospects: The 2017 Revision. United Nations, New York.

Vezzulli, L., Colwell, R.R., Pruzzo, C. et al. (2013). Ocean warming and spread of pathogenic vibrios in the aquatic environment. Microbial Ecology, 65, pp. 817-825.

Von Moos, N., Burkhardt-Holm, P. and Kohler, A. (2012). Uptake and effects of micro plastics on cells and tissue of the blue mussel Mytilus edulis L. after an experimental exposure. Environmental Science and Technology, 46, pp. 11327-11335.

Waite, R., Beveridge, M., Brummett, R., Castine, S., Chaiyawannakarn, N., Kaushik, S., Mungkung, R., Nawapakpilai, S., Phillips, M. (2014). Improving productivity and environmental performance of aquaculture. In: Institute W.R. (Ed.), Creating a Sustainable Food Future, pp. 1-49. World Resources Institute, Washington, DC.

Ward, T. and Phillips, B. (2008). Seafood Ecolabelling: Principles and Practice. WileyBlackwell, Oxford.

Werschkun, B., Banerji, S., Basurko, O.C., David, M., Fuhr, F., Gollasch, S. et al (2014). Emerging risks from ballast water treatment: the run-up to the international Ballast water management convention. Chemosphere, 112, pp. 256-266 
Wilcove, D.S., Rothstein, D., Dubow, J., Phillips, A. and Losos, E. (1998). Quantifying threats to imperilled species in the United States. Bioscience, 48, pp. 607-615.

Williams, F., Eschen, R., Harris, A., Djeddour, D., Pratt, C., Shaw, R.S., Varia, S., Lamontagne-Godwin, J., Thomas, S.E. and Murphy, S.T. (2010). The economic cost of invasive non-native species on Great Britain. Wallingford: CABI. Available at: www.cabi.org [Accessed 27 ${ }^{\text {th }}$ May 2018].

Winterbourn, J.B., Clements, K., Lowtherm J. A., Malham, S.K., McDonald, J.E. and Jones, D.L. (2016). Use of Mytilus edulis biosentinels to investigate spatial patterns of norovirus and faecal indicator organism contamination around coastal sewage discharges. Water Research, 105, pp. 241-250.

WHO. (2010). Safe management of shellfish and harvest waters. Edited by Rees, G., Pond, K., Kay, D., Bartram, J. and Santo Domingo, J. ISBN: 9781843392255. Published by IWA Publishing, London, UK. Available at: http://apps.who.int/iris/bitstream/handle/10665/44101/9789241563826_eng.pdf;jsessi

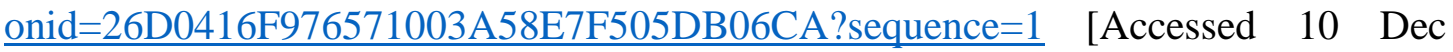
2018].

Youlian, P., Bates, S. and Cembella, A.D. (1998). Environmental stress and domoic acid production by Pseudo-nitzschia: a physiological perspective. Natural Toxins, 6, pp. $127-153$ 